\title{
Regulation of Cdc42 for polarized growth in budding yeast
}

\author{
Kristi E. Miller ${ }^{1,2}$, Pil Jung Kang ${ }^{1}$ and Hay-Oak Park ${ }^{1, *}$ \\ ${ }^{1}$ Department of Molecular Genetics, The Ohio State University, Columbus, $\mathrm{OH} 43210$. \\ 2 Present address: Department of Biochemistry and Cell Biology, The Geisel School of Medicine at Dartmouth, Hanover, NH 03755. \\ * Corresponding Author: \\ Hay-Oak Park, Department of Department of Molecular Genetics, The Ohio State University, 484 West 12th Ave, Columbus, OH \\ 43210; Phone: (614) 688-4575; Fax: 614-292-4466; E-mail: park.294@osu.edu
}

\begin{abstract}
The Rho GTPase Cdc42 is a central regulator of cell polarity in diverse cell types. The activity of Cdc42 is dynamically controlled in time and space to enable distinct polarization events, which generally occur along a single axis in response to spatial cues. Our understanding of the mechanisms underlying Cdc42 polarization has benefited largely from studies of the budding yeast Saccharomyces cerevisiae, a genetically tractable model organism. In budding yeast, Cdc42 activation occurs in two temporal steps in the G1 phase of the cell cycle to establish a proper growth site. Here, we review findings in budding yeast that reveal an intricate crosstalk among polarity proteins for biphasic Cdc42 regulation. The first step of Cdc42 activation may determine the axis of cell polarity, while the second step ensures robust Cdc42 polarization for growth. Biphasic Cdc42 polarization is likely to ensure the proper timing of events including the assembly and recognition of spatial landmarks and stepwise assembly of a new ring of septins, cytoskeletal GTPbinding proteins, at the incipient bud site. Biphasic activation of GTPases has also been observed in mammalian cells, suggesting that biphasic activation could be a general mechanism for signal-responsive cell polarization. Cdc42 activity is necessary for polarity establishment during normal cell division and development, but its activity has also been implicated in the promotion of aging. We also discuss negative polarity signaling and emerging concepts of Cdc42 signaling in cellular aging.
\end{abstract}

doi: $10.15698 /$ mic2020.07.722

Received originally: 24.02 .2020

in revised form: 30.04 .2020 ,

Accepted 04.05.2020,

Published 19.05.2020.

Keywords: cell polarity, Rho GTPase, Saccharomyces cerevisiae, spatial cuedirected cell polarization, positive and negative feedback regulation, cell cycle.
Abbreviations:
CDK-cyclin-dependent kinase, CRM - cytokinesis remnants, $D H-D b l$ homology,
GAP - GTPase activating protein, $G D I$ - guanine nucleotide dissociation inhibitor,
GEF-guanine-nucleotide exchange factor,
GTPase-guanosine triphosphatase, PM - plasma membrane, $R L S$ - replicative lifespan, WT - wild type.

\section{INTRODUCTION}

Cells within a multicellular organism or unicellular organisms such as yeast and bacteria exhibit some form of polarity in order to carry out specialized functions. Cell polarization involves polarized organization of cell shape or cellular components including organelles, proteins, or RNAs. Establishing and maintaining polarity is essential for cellular processes including differentiation, chemotaxis, morphogenesis, cell movement, and cell division [1, 2]. The highly conserved Rho GTPase Cdc42 regulates polarity development across the eukaryotic kingdom. Like other Rho GTPases, Cdc42 cycles between an active GTP-bound state and an inactive GDP-bound state. Guanine-nucleotide exchange factors (GEFs) activate Cdc42 by catalyzing the exchange of GDP for GTP, whereas GTPase activating proteins (GAPs) enhance its intrinsic GTPase activity, facilitating the conversion of $\mathrm{Cdc} 42$ to its inactive form. The active Cdc42 re- cruits and/or regulates a variety of downstream effectors (Figure 1; Table 1). Localized activation of Cdc42 has been shown to be a key event leading to cell polarization in yeast and mammalian cells $[3,4]$. While the universal role of Cdc42 in establishing and maintaining tissue/cell polarity is critical for normal cell division and is also implicated in tumor suppression, Cdc42 activation has been suggested to contribute to tumor cell invasion and migration as well as cellular aging [5-7]. Thus, uncovering the molecular mechanisms underlying Cdc42 polarization will provide insights into how cell growth is regulated and how perturbation of Cdc42 activity may lead to disease and aging.

Polarized growth is generally directed by intracellular or extracellular spatial cues such as cell-cell contacts, chemoattractants, and cortical landmarks. Budding yeast is an excellent model system to study cell polarity because it displays pronounced cell polarization during various phases 


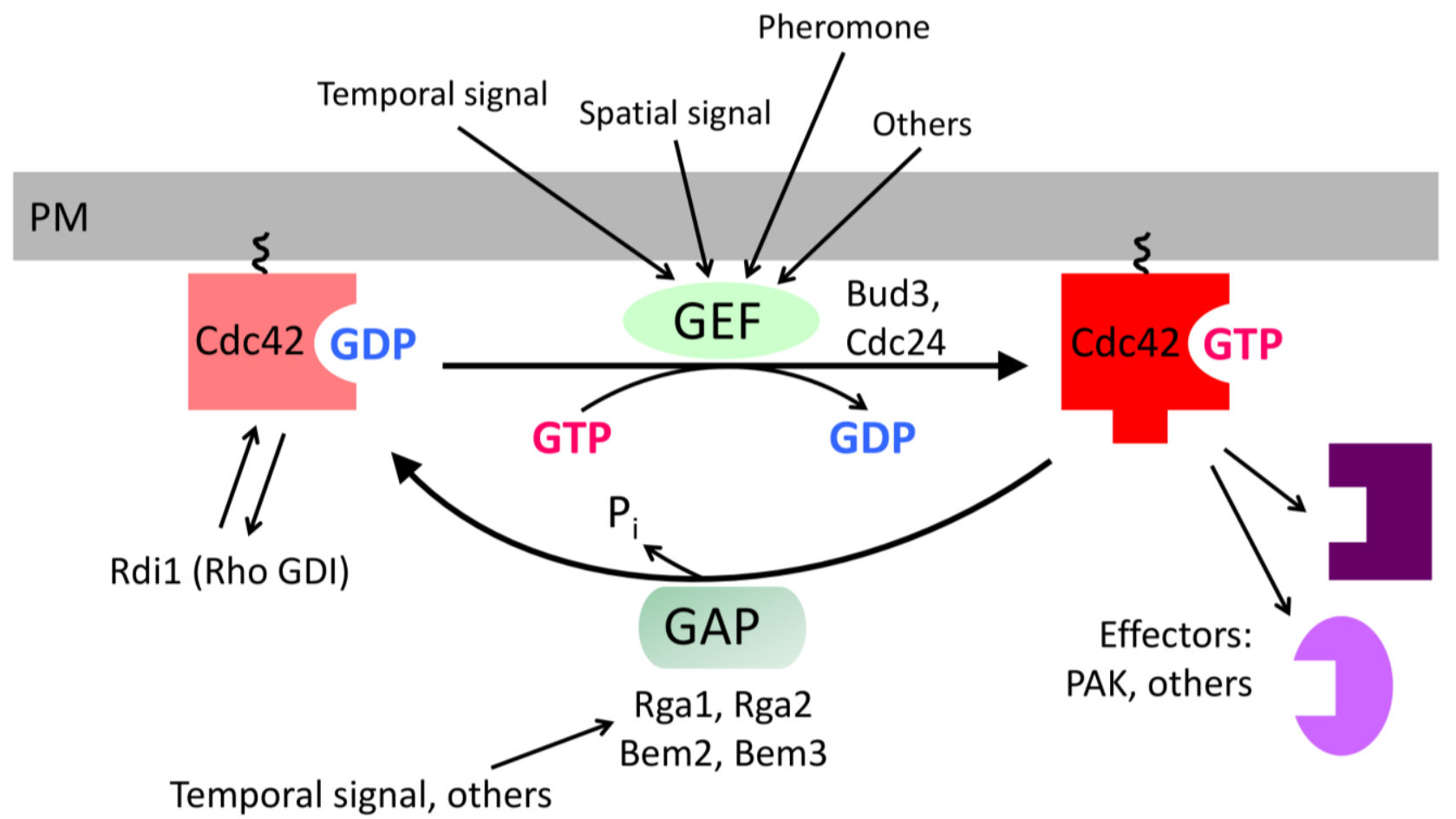

FIGURE 1: The Cdc42 GTPase and its regulators in budding yeast. Cdc42 activity is regulated by at least three types of regulators: the GEFs, Cdc24 and Bud3; the GAPs, Rga1, Rga2, Bem2, and Bem3; and the GDI Rdi1. These regulators are likely to mediate the regulation of Cdc42 in response to internal and external signals. Cdc42 regulates the organization of the actin and septin cytoskeletons and polarized secretion via its downstream effectors including PAKs.

of its life cycle, such as budding during vegetative growth and mating between two haploid cells of opposite mating types. During the mitotic cell cycle, yeast cells undergo oriented cell division by choosing a specific bud site depending on their cell type. Haploid $\mathbf{a}$ and $\alpha$ cells bud in an axial pattern, in which both mother and daughter cells select a new bud site adjacent to their immediately preceding division sites. In contrast, diploid a/ $\alpha$ cells bud in the bipolar pattern, in which daughter cells predominantly bud at the pole distal to the division site, and mother cells can choose a new bud site near either pole [8-10] (Figure 2). These different patterns of growth require cell-typespecific cortical cues and the Rsr1 GTPase module, composed of Rsr1 (also known as Bud1), its GAP Bud2, and its GEF Bud5 [11-15]. Multiple genetic and physical interactions suggest that the Rsr1 GTPase module guides Cdc42 and its regulators to direct organization of the actin cytoskeleton and septin filaments for polarized growth to the selected site [11, 13, 16-21].

Polarized growth and cytokinesis in budding yeast are coordinated with cell cycle progression. Yet how polarity establishment is temporally regulated in the G1 phase is still largely unknown. The cyclin-dependent kinase Cdc28 (CDK1), complexed with a G1 cyclin, is required to promote bud emergence as well as other key events in the cell cycle (such as DNA replication and spindle pole body duplication) once cells pass through the irreversible commitment point known as 'Start' $[22,23]$, which is equivalent to 'restriction point' in mammalian cells. The Start transition corresponds to the time of the nuclear exit of approximately $50 \%$ of Whi5, a transcriptional repressor [24], which partitions the G1 phase into two temporal steps. The first step $\left(T_{1}\right)$ is critical for cell size control and depends on the upstream cyclin Cln3 [25]. Whi5, which is functionally analogous to mammalian retinoblastoma (RB), inhibits two heterodimeric transcription factor complexes SBF (Swi4-Swi6) and MBF (Mbp1-Swi6), which dictate G1/S transcription. Phosphorylation of Whi5 initially by Cln3-CDK1 drives its exit from the nucleus, leading to activation of the G1/S transcriptional program, including expression of the $\mathrm{G} 1$ cyclins $\mathrm{Cln} 1$ and Cln2, which trigger further inactivation of Whi5 $[26,27]$. The second step $\left(T_{2}\right)$, defined from Start to bud emergence, is cell size-independent [25]. Recent studies have uncovered an intricate crosstalk among the polarity proteins that function in these distinct steps in the G1 phase to promote Cdc42 polarization at the proper time and place, which will be a major focus of this review (see below).

In the absence of spatial cues or Rsr1, yeast cells can still direct polarized growth to a single random site. This spontaneous cell polarization without spatial cues (often referred to as 'symmetry breaking') is thought to rely on positive feedback loops that promote the amplification of small stochastic clusters of $\mathrm{Cdc} 42$. One of these positive feedback mechanisms may rely on actin-based transport of Cdc42, whereas the other involves the Cdc42-signaling network that includes a complex of the scaffold protein 
TABLE 1. The Cdc42 and Rsr1 GTPses and their regulators and effectors.

\begin{tabular}{|c|c|c|c|}
\hline $\begin{array}{l}\text { Name of protein or } \\
\text { protein complex }\end{array}$ & Protein activity & $\begin{array}{l}\text { Function in relation to Cdc42 polarization in } \\
\text { haploid cells }\end{array}$ & $\begin{array}{l}\text { Selected Refer- } \\
\text { ences }\end{array}$ \\
\hline Cdc42 & Rho GTPase & $\begin{array}{l}\text { Essential for polarity establishment and mainte- } \\
\text { nance }\end{array}$ & {$[61,87,106-109]$} \\
\hline Cdc24 & GEF for Cdc42 & $\begin{array}{l}\text { Essential for polarity establishment and mainte- } \\
\text { nance } \\
\text { Activates Cdc42 likely after Start }\end{array}$ & 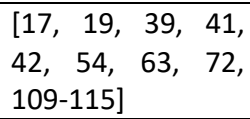 \\
\hline Bud3 & $\begin{array}{l}\text { GEF for Cdc42; Axial land- } \\
\text { mark }\end{array}$ & $\begin{array}{l}\text { Essential for axial budding of haploid a and } \alpha \text { cells } \\
\text { Activates Cdc } 42 \text { before Start }\end{array}$ & $\begin{array}{l}{[14,37,40,116,} \\
117]\end{array}$ \\
\hline Rga1 & GAP for $\mathrm{Cdc} 42$ & $\begin{array}{l}\text { Essential for preventing polarization within old cell } \\
\text { division sites }\end{array}$ & $\begin{array}{l}{[44,46,49,58,} \\
59,94]\end{array}$ \\
\hline Rga2, Bem2, Bem3 & GAP for Cdc42 (and Rho1) & $\begin{array}{l}\text { Important for polarity regulation and septin ring } \\
\text { assembly }\end{array}$ & $\begin{array}{l}{[60,88,89,94,} \\
118-123]\end{array}$ \\
\hline Rdi1 & $\begin{array}{l}\text { GDI for Cdc42 (and Rho1 and } \\
\text { Rho4) }\end{array}$ & $\begin{array}{l}\text { Important for cycling of } \mathrm{Cdc} 42 \text { and other Rho } \\
\text { GTPases between the cytosol and PM during cell } \\
\text { polarization }\end{array}$ & {$[75-77,124,125]$} \\
\hline Bem1 & $\begin{array}{l}\text { Scaffold for GEF-based ampli- } \\
\text { fication of Cdc42 activation }\end{array}$ & $\begin{array}{l}\text { Forms a complex with Cdc24 and PAK (Cla4/Ste20) } \\
\text { important for robust Cdc42 polarization after Start; } \\
\text { Interacts with Exo70 and Rsr1-GDP }\end{array}$ & $\begin{array}{l}{[17,21,63,64,} \\
68,71,72,109, \\
118,126,127]\end{array}$ \\
\hline Cla4 & $\begin{array}{l}\text { PAK (p21-activated kinase) } \\
\text { Effector of Cdc42 }\end{array}$ & $\begin{array}{l}\text { Part of Bem1 polarity complex important for } \mathrm{Cdc} 42 \\
\text { polarization }\end{array}$ & $\begin{array}{l}{[63,70,72,113,} \\
128-130]\end{array}$ \\
\hline Ste20 & PAK, Effector of Cdc42 & $\begin{array}{l}\text { Part of Bem1 polarity complex important for } \mathrm{Cdc} 42 \\
\text { polarization }\end{array}$ & {$[65,70,131-133]$} \\
\hline Gic1, Gic2 & Related effectors of Cdc42 & $\begin{array}{l}\text { Act in parallel with Rsr1 in Cdc42 polarization prior } \\
\text { to Start } \\
\text { Stabilize Cdc42-GTP on the PM }\end{array}$ & {$[61,87,134-137]$} \\
\hline $\operatorname{Rax1,} \operatorname{Rax2}$ & $\begin{array}{l}\text { Interdependent transmem- } \\
\text { brane proteins }\end{array}$ & $\begin{array}{l}\text { Localize to the bud tip and division site; Stably } \\
\text { inherited at old division sites; Anchor negative } \\
\text { polarity cues Nba1 and Nis1; Important for proper } \\
\text { targeting of the bipolar landmark. }\end{array}$ & {$[34,49,100,101]$} \\
\hline Aim44 (= Gps1) & Bud neck associated protein & $\begin{array}{l}\text { Negative regulator of Cdc42 signaling at the divi- } \\
\text { sion site that functions in parallel with Rga1; } \\
\text { Scaffold for Nba1 and Nis1 }\end{array}$ & {$[98,138]$} \\
\hline Nba1, Nis1 & Negative polarity complex & $\begin{array}{l}\text { Anchored by Rax1/2 at old cell division sites } \\
\text { Recruits Rga1 via direct interaction between Nba1 } \\
\text { and Rga1 }\end{array}$ & {$[34,49]$} \\
\hline Bni1 & $\begin{array}{l}\text { Formin, nucleates actin fila- } \\
\text { ments; } \\
\text { Effector of Cdc42 and Rho1; } \\
\text { Polarisome component }\end{array}$ & $\begin{array}{l}\text { Promotes the assembly of actin cables and actin } \\
\text { rings, important for exocytosis, cytokinesis, and } \\
\text { spindle orientation. }\end{array}$ & [139-147] \\
\hline Exo70 & Exocyst subunit & $\begin{array}{l}\text { Required for the tethering of post-Golgi vesicles to } \\
\text { the PM } \\
\text { Interacts with Cdc42, Bem1, and Rho3 }\end{array}$ & {$[64,148-150]$} \\
\hline $\begin{array}{l}\text { Bud4, Axl1, and Axl2 } \\
\text { (including Bud3) }\end{array}$ & Axial landmark & $\begin{array}{l}\text { Intrinsic positional marker for } \mathrm{Cdc} 42 \text { polarization in } \\
\text { haploid } \mathbf{a} \text { and } \alpha \text { cells }\end{array}$ & $\begin{array}{l}{\left[\begin{array}{l}14,84-86,117, \\
151-157]\end{array}\right.} \\
\end{array}$ \\
\hline Rsr1 (=Bud1) & Ras GTPase & $\begin{array}{l}\text { Essential for proper bud-site selection } \\
\text { Interacts with Cdc } 24, \text { Cdc } 42 \text {, and Bem } 1 \\
\text { Promotes Cdc42 polarization by linking the spatial } \\
\text { cue to } C d c 42 \text { prior to Start }\end{array}$ & $\begin{array}{l}{[11,14,17,18,} \\
20,21,61,67]\end{array}$ \\
\hline Bud2 & GAP for Rsr1 & Essential for proper bud-site selection & $\begin{array}{l}{[12,15,46,158-} \\
160]\end{array}$ \\
\hline Bud5 & GEF for Rsr1 & $\begin{array}{l}\text { Essential for proper bud-site selection } \\
\text { Interacts with the axial and bipolar landmark }\end{array}$ & {$[13,86,161-163]$} \\
\hline
\end{tabular}


A

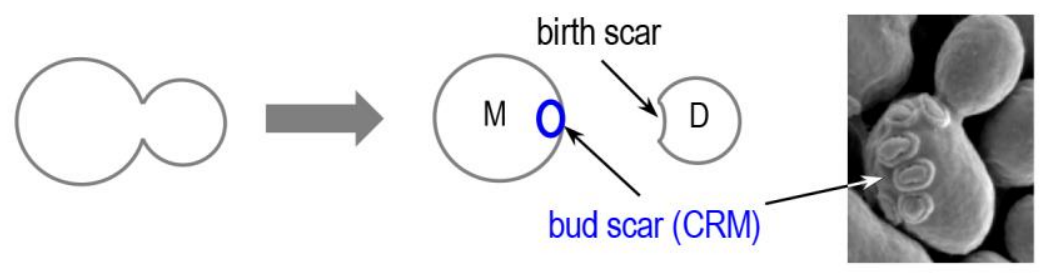

B
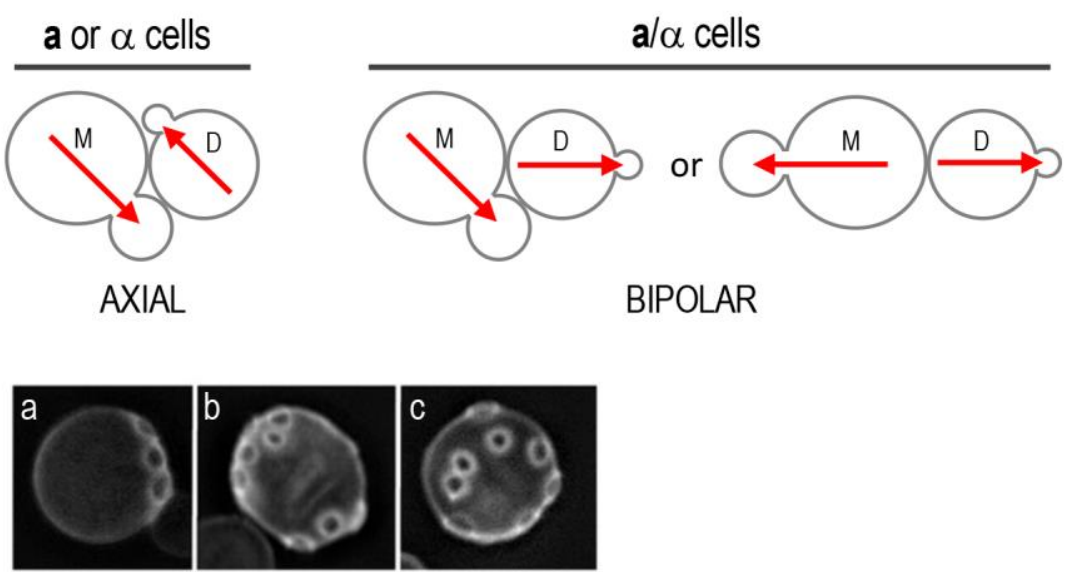

FIGURE 2: Oriented cell divisions of $S$. cerevisiae. (A) Each cell division leaves a bud scar that marks the site of division on the mother cell surface and birth scar on daughter cell. Successive divisions produce distinct patterns of bud scars (also called cytokinesis remnants: CRMs). Bud scars can be visualized by scanning electron microscopy (image on the right) or by staining with the dye Calcofluor (as shown in B). Electron micrograph was taken from Ref. [44] with permission. (B) Axial and bipolar patterns of bud-site selection in S. cerevisiae. Red arrows denote the axes of cell polarization. Below, the patterns of bud scars on the yeast cell surface resulting from the different modes of budding are visualized after Calcofluor staining: (a) axial pattern; (b) bipolar pattern; and (c) random budding by a mutant (such as $r s r 1 \Delta$ ). Micrographs were published previously [20].
Bem1, Cdc24 (a Cdc42 GEF), and a Cdc42 effector p21activated kinase (PAK), although the details of these mechanisms are still under debate. In vivo analyses and computational modeling have also suggested a negative feedback loop that enhances robustness to the polarity circuit. Symmetry breaking has been covered in greater detail in a number of reviews [28-31], and we refer interested readers to these sources and references therein. These key players in symmetry breaking are discussed later in this review with respect to their role in spatial-cue-dependent polarization.

Another key aspect of yeast budding is asymmetric cell division, resulting in mother and daughter cells with distinct characteristics including mother cell-specific aging [32]. Mother cells progressively age and produce a finite number of daughter cells, referred to as replicative lifespan (RLS). In contrast, daughter cells are born with full replicative potential. Interestingly, however, aged cells sometimes undergo symmetric cell division, and thus daughter cells from very old mothers often display reduced lifespans [33]. Negative polarity factors in Cdc42 signaling have been implicated in yeast aging [34]. Yet the causal factors or consequence of aging still remain elusive [35]. In this review, we discuss polarity establishment during yeast budding. In particular, we focus on recent findings that cover regulation of $\mathrm{Cdc} 42$ in relation to the two temporal phases of $\mathrm{G} 1$. We also discuss the importance of negative polarity signaling and the possible implication of $\mathrm{Cdc} 42$ signaling in cellular aging.

\section{BIPHASIC CDC42 POLARIZATION IN THE G1 PHASE The first step determines the axis of cell polarity}

Haploid a and $\alpha$ cells select a new bud site adjacent to the previous division site. This axial budding pattern depends on the deposition of a transient cortical landmark, referred to as the axial landmark, composed of Bud3, Bud4, Axl1, and $A x \mid 2$ (see [36] and references therein). While earlier studies suggested a morphogenetic hierarchy from spatial cues to Cdc42 polarization via the Rsr1 GTPase module, our unexpected finding of Bud3 as a Cdc42 GEF has uncovered a more complex regulatory mechanism underlying $\mathrm{Cdc} 42$ polarization in correlation with cell cycle progression [37]. Bud3 contains a conserved Dbl homology (DH) domain, which is necessary for GEF activity of Rho GEFs [38], and functions as a GEF for $\mathrm{Cdc} 42$ both in vitro and in vivo [37]. Prior to this finding, Cdc24 had been known as the sole Cdc42 GEF in budding yeast [39]. Bud3 localizes to the mother-bud neck (i.e., future cell division site), peaking in $M$ phase, and stays at the division site until the next G1 phase [40]. In contrast, the majority of $\mathrm{Cdc} 24$ is sequestered in the nucleus in late $M$ and early $G 1$ phases via interaction with the nuclear anchor Far1 in haploid cells [41, 42]. Consistent with these localization patterns, Bud3 is mainly responsible for activation of Cdc42 in early $\mathrm{G1}$, accounting for Cdc42 polarization soon after cytokinesis, while Cdc24 activates Cdc42 in late G1. The distribution and activity of $\mathrm{Cdc} 42$ in vivo has been quantitatively defined by live-cell imaging using a fluorescent probe carrying a PBD (p21-binding domain), which contains CRIB (Cdc42/Rac-interactive binding motif) and specifically interacts with Cdc42-GTP in budding yeast [43-45]. Using this biosensor, we showed that yeast cells with a mutation in 
the Bud3 DH domain with defective GEF activity display greatly diminished $\mathrm{Cdc} 42$ polarization in early $\mathrm{G} 1 \mathrm{com}$ pared to wild type (WT). In contrast, a temperature sensitive cdc24 mutant was able to polarize Cdc42 normally in early $\mathrm{G} 1$ but failed in subsequent $\mathrm{Cdc} 42$ polarization and arrested as unbudded cells at the non-permissive temperature [37]. Importantly, this study provided the first evidence for stepwise $\mathrm{Cdc} 42$ polarization in correlation with two temporal steps in the G1 phase (Figure 3).

As a component of the axial landmark complex, Bud3 likely functions in liking spatial information from the cell division site to the next bud site by triggering the initial activation of $\mathrm{Cdc} 42$ for polarity establishment in haploid cell types. Then, how is a single, new bud site established near the last division site even though Bud3 (and other components of the axial landmark) form a ring at the division site? This question is especially relevant because the perimeter of the ring appears large enough to accommodate multiple sites. A subsequent study from our group [46] addressed this question and uncovered the potential involvement of negative and positive feedback loops in selection of a proper bud site during axial budding. Live-cell imaging showed that the Cdc42-GTP level fluctuates around the septin ring until the axis of $\mathrm{Cdc} 42$ polarization becomes stabilized in mid G1. This wandering behavior of Cdc42-GTP cluster is particularly evident in daughter cells during the first phase of $\mathrm{G1}$, which lasts much longer in daughter cells compared to mother cells. The output of delayed negative feedback, where accumulation of a molecule leads to its own dispersal so that the concentration does not reach a steady state, results in oscillatory or wandering dynamics of a molecule $[43,47,48]$. To explain these distinct dynamics of Cdc42-GTP cluster in mother versus daughter cells, we used mathematical modeling. We considered a generic model of particle density of the membrane bound $\mathrm{Cdc} 42$ on a two-dimensional computational domain with the axial landmark as a ring in the center. Initially, we assumed two phases to mimic two temporal steps of the G1 phase with two sequential positive feedback loops. We also considered the distribution of the Cdc42 GAP Rga1 that localizes as a ring at the division site to inhibit Cdc42 re-polarization. However, simulations from this initial biphasic modeling with the fixed distribution of Rga1 as a homogeneous ring at the division site led to budding within the division site. Surprisingly, by reexamining Rga1 localization, we found that Rga1 exhibits a fragmented ring-like structure or amorphous distribution at the division site during cytokinesis and G1 phase. This time-dependent Rga1 distribution at the division site is necessary for proper bud-site selection [46]. We thus implemented this new pattern of Rga1 localization and assumed putative delayed negative feedback together with positive feedback in the first phase in our biphasic model. Importantly, when we assumed transient negative feedback with different durations to mimic the lengths of the first temporal step of G1 in mother and daughter cells (typically about $3 \mathrm{~min}$ in mother cells and $15 \mathrm{~min}$ in daughter cells) in addition to sequential positive feedback loops, this modeling recapitulated the distinct $\mathrm{Cdc} 42$ polarization dynamics in mother versus daughter cells as observed in vivo [46]. Therefore, pre-Start Cdc42 polarization likely involves negative and positive feedback loops that link the axial landmark to $\mathrm{Cdc} 42$ polarization $[37,46]$. Furthermore, the correlation of spatial distribution of Rga1 with cell cycle progression is important to fine-tuning the axis of cell polarity in budding yeast $[46,49]$.

Polarity proteins often exhibit oscillatory or wandering behavior, as observed in plants [50], mammalian cells [51], fission yeast [47], and budding yeast [46, 52]. Thus, delayed negative feedback may be a common mechanism underlying control of GTPase function in many organisms. In theory, there could be two possible scenarios of how active $\mathrm{Cdc} 42$ induces its own inactivation: Cdc42-GTP activates its inhibitor (e.g., a Cdc42 GAP) or inhibits its activator (e.g., a Cdc42 GEF). It has been suggested that negative feedback might involve inactivation of the Cdc24 GEF during symmetry breaking in diploid budding yeast [53]. However, this is unlikely to occur in haploid cells during the first phase of $\mathrm{G} 1$ because the majority of $\mathrm{Cdc} 24$ is sequestered in the nucleus until Start $[41,42,54]$. While a critical study has yet to uncover the precise mechanism, negative feedback during pre-Start $\mathrm{Cdc} 42$ polarization in haploid cells may potentially involve the Cdc42 GEF Bud3 or its GAP Rga1. Bud3 contains numerous putative phosphorylation

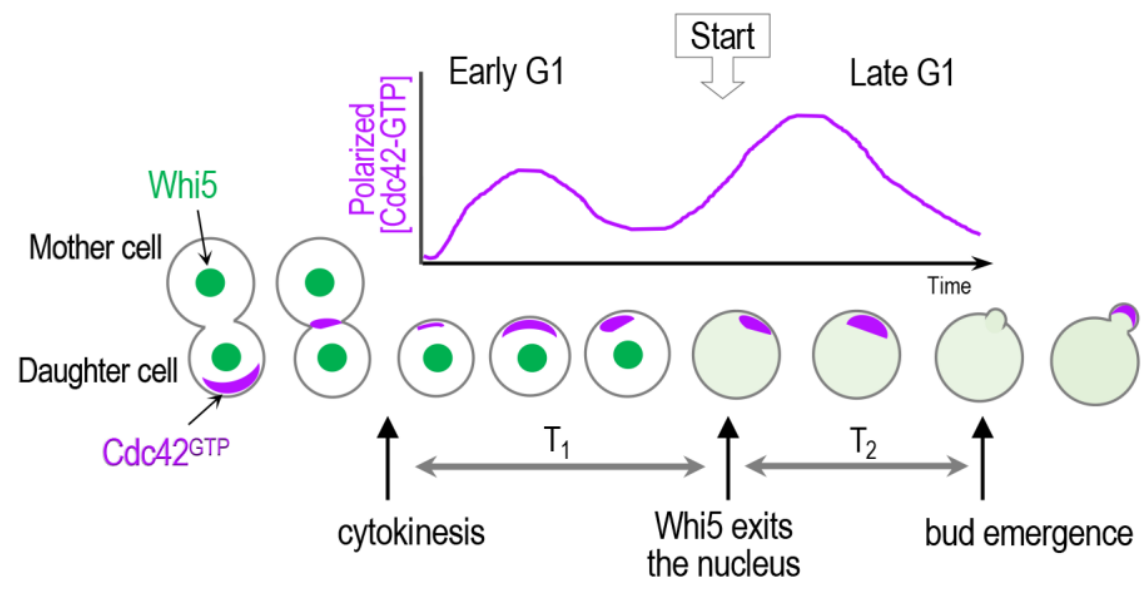

FIGURE 3: A scheme of biphasic Cdc42 polarization in the $\mathbf{G 1}$ phase. Cdc42 polarization occurs stepwise triggered by its two GEFs: first by Bud3 and subsequently by $\mathrm{Cdc} 24$ [37]. Whi5 partitions the G1 phase into two temporal steps, and the 'Start' transition corresponds to the time of the nuclear exit of approximately $50 \%$ of Whi5 [24]. The sites of Cdc42 polarization prior to the onset of cytokinesis and until a new bud appears are marked with purple color 
and ubiquitination sites [55-57], but it is currently unknown how Bud3 is regulated to promote Cdc42 activation specifically prior to Start. Rga1 is also required for proper bud-site selection [58-60] and prevents re-budding at the same site by inactivating Cdc42 from the division site [44], although its regulation is not fully understood (see below).

Does biphasic Cdc42 polarization occur only in cells budding in the axial pattern? Is stepwise activation of Cdc42 necessary to ensure sequential execution of the processes in the $\mathrm{G} 1$ phase? Our recent study that included analyses of temperature-sensitive $c d c 42$ alleles found that cells cannot traverse the $\mathrm{G} 1$ phase without $\mathrm{Cdc} 42$ polarization prior to Start [61]. Remarkably, a positive feedback loop involving two redundant Cdc42 effector proteins Gic1 and Gic2 is likely to act in parallel with Rsr1 in Cdc42 polarization prior to Start (Figure 4). As suggested in a previous report [62], cells lacking Rsr1 and both Gic proteins fail to polarize despite the presence of all components implicated in symmetry breaking. Specifically, depletion of Rsr1 and both Gic1 and Gic2 prevents cells from polarizing Cdc42 during the first phase of $\mathrm{G1}$ and results in cell cycle arrest. Genetic data and FRAP (fluorescent recovery after photobleaching) analyses suggest that despite the shared role in pre-Start Cdc42 polarization, Rsr1 and Gic1/Gic2 may promote $\mathrm{Cdc} 42$ polarization via distinct mechanisms: the Rsr1 GTPase module links the spatial cue to $\mathrm{Cdc} 42$, and its function depends on local activation of $\mathrm{Cdc} 42$ by Bud3. In contrast, Gic1 and/or Gic2 interact with Cdc42-GTP and then stabilize Cdc42-GTP on the plasma membrane (PM), reduc- ing lateral diffusion of Cdc42-GTP [61]. It is interesting to note that $r s r 1 \Delta$ cells display sporadic and relatively weaker pre-Start Cdc42 polarization compared to WT. Yet both WT and $r s r 1 \Delta$ cells display robust $\mathrm{Cdc} 42$ polarization in the second phase of G1 [46]. Pre-Start Cdc42 polarization by Gic1/Gic2 is likely essential in the absence of Rsr1 and thus in cells undergoing symmetry breaking. Interestingly, another study has also observed pre-Start Cdc42 polarization by locally recruiting Cdc24 by optogenetics in $r s r 1 \Delta$ cells. But recruitment of Bem 1 before Start did not induce the positive feedback loop, suggesting that there are two distinct modes of $\mathrm{Cdc} 42$ polarization before and after Start [63]. Therefore, biphasic Cdc42 polarization is likely to occur in yeast cells regardless of their budding pattern.

While Rsr1 bound to GTP positively regulates polarity establishment, Rsr1 bound to GDP likely inhibits premature polarization through its interaction with the scaffold protein Bem1 [21]. Consistent with an earlier in vitro analysis [17], Rsr1 interacts with Bem1 preferentially in its GDPbound state in vivo, and this interaction takes place during late $\mathrm{M}$ and early $\mathrm{G} 1$ phases [21]. Rsr1-GDP associates specifically with a part of the Bem1 Phox homology (PX) domain, which overlaps with a region previously shown to interact with Exo70, an exocyst component [64]. Furthermore, expression of a constitutively GDP-bound Rsr1 interferes with Bem1's association with Exo70, inhibiting Bem1dependent Exo70 polarization, and also leads to delayed Cdc42 polarization and bud emergence. Consistent with these in vivo findings, mathematical modeling predicts that

\section{Early $\mathrm{G} 1\left(\mathrm{~T}_{1}\right)$}

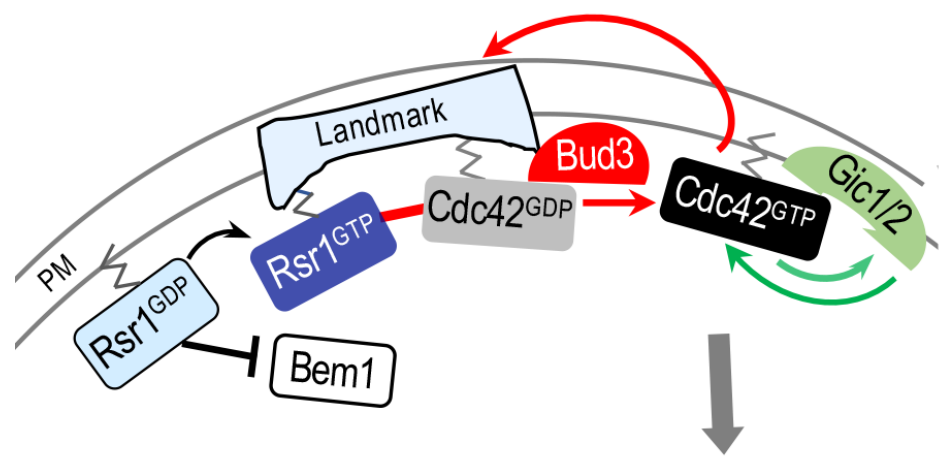

Mid - Late G1 $\left(T_{2}\right)$

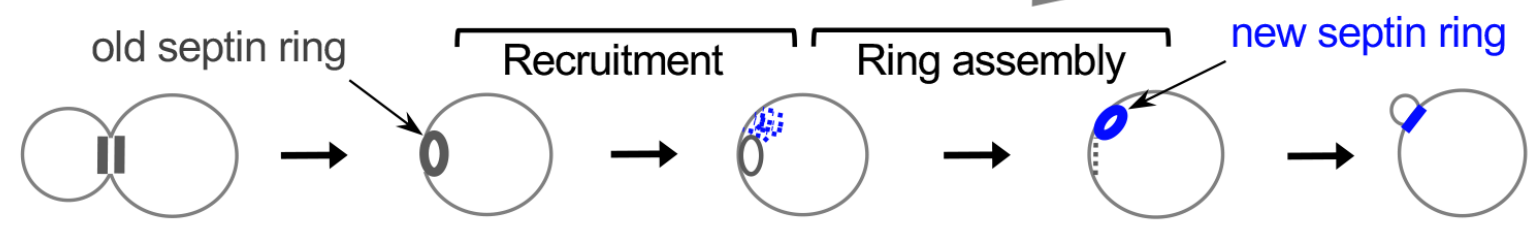

FIGURE 4: Model for biphasic Cdc42 polarization coupled to stepwise assembly of a new septin ring during axial budding. During $T_{1}$, two positive feedback loops likely operate: one involving Bud3 and Rsr1 (marked with red arrows and line); another involving Gic1/2 (marked with green arrows). The Bem1-mediated positive feedback loop likely operates during $\mathrm{T}_{2}$ (gray lines and arrows). For simplicity, some other known links are omitted, including the link between the axial landmark and the Rsr1 GTPase module; and the link between Rsr1-GTP and Cdc24 (see text). Stepwise assembly of the septin ring in correlation with Cdc42 polarization during each temporal step in G1 is shown below: gray and blue rings denote old and new septin rings, respectively. Blue dots and gray dotted line denote newly recruited septin 'clouds' and disassembling old ring, respectively. Modified from Refs. [61] and [21]. 
Bem1 is unable to promote Cdc42 polarization in early G1 in the presence of Rsr1-GDP. Thus, Rsr1-GDP likely interferes with the role of Bem1 in Cdc42 polarization and polarized secretion during the first phase of $\mathrm{G} 1$ in both haploid and diploid cells [21]. Importantly, this study suggests that Bem1-mediated positive feedback, which is critical for symmetry breaking, does not occur before Start because of its association with Rsr1-GDP, consistent with a previous finding that Bem1 functions in the polarity complex after Start [63] (see below). In contrast, another report argues that Bem1 and Cdc24 are active before Start in WT diploid cells [65]. The reason for this discrepancy is not clear, and further studies are required to clarify this issue.

\section{The second step leads to robust polarization to the incipi- ent bud site}

After Start, active Cdc28 (CDK1) complexed with a G1 cyclin (Cln1 or Cln2) phosphorylates Far1, a CDK1 inhibitor and a nuclear anchor of Cdc24, leading to subsequent degradation of Far1 and thus release of Cdc24 from the nucleus in haploid cells $[42,66]$. Cdc24 is then directed to the selected site of polarized growth through association with Rsr1GTP $[16,17,67]$. In the absence of spatial cues or a component of the Rsr1 GTPase module, yeast cells can still polarize $\mathrm{Cdc} 42$ at a single random site that is determined around the transition from the first to second temporal step in the G1 phase [46]. This implies that similar mechanisms may operate to reinforce polarity establishment after Start at a single chosen site during spatial-cue directed cell polarization as well as during symmetry breaking.

Previous studies on symmetry breaking have suggested that Bem1 mediates positive feedback for robust $\mathrm{Cdc} 42$ polarization $[68,69]$. Bem1 was initially identified to play an essential role in symmetry breaking based on synthetic lethality of a $r s r 1 \Delta$ bem $1 \Delta$ double mutant [68]. Bem1 was also found to be essential for cell polarization when actin is inhibited [69]. Expression of an artificial fusion protein of GEF Cdc24 - PAK Cla4 was able to rescue the lethality of the $r s r 1 \Delta$ bem $1 \Delta$ mutant and drive polarization, establishing the role of the scaffold protein Bem1 in linking a Cdc42 GEF and a PAK for symmetry breaking [70]. A recent study employing an optogenetic strategy [63] provides a direct demonstration of the Bem1-mediated positive feedback loop. Remarkably, this study also suggests that the Bem1mediated positive feedback loop requires CDK1-mediated phosphorylation: the Bem1 optogenetic construct could not induce Cdc42 cluster formation prior to the Start transition; and the Cdc24 optogenetic construct also could not recruit Bem1 prior to this transition [63]. Although it has not been directly tested whether this mechanism is also involved in spatial-cue directed cell polarization, these polarity factors are required for budding of WT cells. While a study argues that Bem1 promotes $\mathrm{Cdc} 42$ polarization prior to Start [65], an increasing number of evidence suggests that Bem1 functions after Start: the GEF activity of Cdc24 is enhanced by Bem1 [71, 72], which associates with Cdc24 after Start in cells lacking RSR1 [63]. In addition, Bem1's role in promoting actin-independent localization of Exo70 is inhibited by Rsr1-GDP prior to Start [21] (see Figure 4).

Since Cdc42 promotes the organization of the actin cytoskeleton, which serves as tracks for the delivery of secretory vesicles, actin may also be involved in a positive feedback loop by promoting transport of $\mathrm{Cdc} 42$ on vesicles. However, the significance of actin-dependent feedback in polarity establishment is still under debate. A number of studies including mathematical modeling have suggested that the actin-dependent feedback loop acts in the generation of robust cell polarity $[73,74]$, which may function in parallel with the Bem1-mediated positive feedback [69]. Although Cdc42 trafficking on vesicles through endo- and exocytosis is slow, GDI (guanine nucleotide dissociation inhibitor)-mediated extraction of Cdc42-GDP can serve for fast recycling of $\mathrm{Cdc} 42$. It has been shown that GDImediated membrane-cytosol shuttling along with actin mediated delivery is necessary to establish a robust and stable Cdc42 polarity site $[75,76]$. In contrast, a number of studies argue against the actin-dependent feedback for polarity establishment. These studies suggest that the slow delivery and low abundance of $\mathrm{Cdc} 42$ on polarized actin cables can lead to dilution of Cdc42 molecules at the polarity site rather than reinforcing polarization [77-81]. Interestingly, however, high-resolution imaging with complementary mathematical modeling indicates that the spatial coordination of opposing membrane trafficking activities via endocytosis and exocytosis allows robust polarity establishment, supporting the positive role of the actin cytoskeleton in polarity establishment [82]. While Cdc42-GTP auto-amplification can drive the clustering of exocytic activity to discrete sites, endocytic corralling ensures the selection of a unique, polarization cluster [82]. Additionally, actin depolymerization destabilizes the polarity cluster in both budding and fission yeasts $[69,83]$. While expression of a GDI-insensitive cdc42 allele is able to promote symmetry breaking, these budding yeast cells display a defect in proper bud-site selection and loss of singularity in budding [83]. Thus, the mechanisms promoting Cdc42 delivery to the PM may not be essential for initial establishment of cell polarity but may be important for robust $\mathrm{Cdc} 42$ polarization leading to bud emergence at a single site, which is particularly critical for the growth and division mode of budding yeast. While further investigation is necessary to fully understand these underlying mechanisms, actinmediated positive feedback of Cdc42 polarization may be more important in the second temporal step of the G1 phase.

\section{Biological outputs of biphasic Cdc42 polarization}

While we have a better understanding of the mechanisms underlying $\mathrm{Cdc} 42$ polarization, critical questions remain including why Cdc42 polarization occurs in two steps during G1. What are the biological outputs of stepwise $\mathrm{Cdc42}$ polarization? In haploid a and $\alpha$ cells, Cdc42 polarization in the first phase of $\mathrm{G} 1$, which is triggered by Bud3, may be important for full assembly of the axial landmark and thus for establishing the polarity axis in the proper orientation. 
This idea has been supported by live-cell imaging and biochemical assays [37]. Each component of the axial landmark likely assembles sequentially at the division site during $M$ and early $G 1$ phase: Bud3 and Bud4 localize to the mother-bud neck first (i.e., future cell division site) through the interaction with septins $[40,84]$ and then recruit the other landmark proteins Axl1 and Axl2 [85]. Once this complex is fully assembled, it can interact with the Rsr1 GEF Bud5 [85, 86]. In contrast, in a bud3 DH domain mutant with defective GEF activity, Bud4 fails to interact with Axl1, and Bud5 poorly associates with Bud4 and Axl1 [37]. Furthermore, Bud4 poorly associates with Axl1 in a temperature-sensitive $c d c 42$ mutant that is specifically defective in axial budding at a semi-permissive temperature, indicating that fully functional $\mathrm{Cdc} 42$ is necessary for axial landmark assembly [37]. Axial landmark assembly is likely critical for further recruitment and activation of $\mathrm{Cdc} 42$ via Rsr1 (and Bud3), leading to Cdc42 polarization at a single incipient bud site around Start. Active Rsr1 is then expected to guide $\mathrm{Cdc} 24$ and $\mathrm{Cdc} 42$ to the proper site for subsequent Cdc42 polarization in the second phase of G1 [16-20, 67]. Although Rsr1-GTP may also play a role in activation of $\mathrm{Cdc} 24$ by facilitating its release from autoinhibition [19], this role of Rsr1 is likely to be mediated by other regulators of Cdc24 [21, 71, 72] (see above).

Cdc42 also plays a key role in septin organization [8789]. An earlier study by $\mathrm{Bi}$ and colleagues suggested that a new septin ring assembles stepwise - septins are first recruited as disorganized 'clouds', which are then converted to a ring [87]. In a subsequent study, which combined livecell imaging and computational modeling, they showed that septins recruited to the site of polarization by active Cdc42 subsequently inhibit $\mathrm{Cdc} 42$ in a negative feedback loop driven by $\mathrm{Cdc} 42$ GAPs. Polarized exocytosis then sculpts the septin patch into a ring, creating a hole that relieves inhibition of $\mathrm{Cdc} 42$ at the site of bud emergence [89]. Our recent study showed that this stepwise assembly of the septin ring occurs in correlation with biphasic Cdc42 polarization in the G1 phase [61]. When Rsr1 and both Gic proteins were depleted, cells failed to polarize $\mathrm{Cdc} 42$ during the first phase of $\mathrm{G} 1$ and as a consequence failed to recruit new septins. Remarkably, overexpression of Cdc42 allowed its own polarization as well as septin recruitment in the absence of Rsr1 and both Gic proteins [61]. Therefore, stepwise regulation of $\mathrm{Cdc} 42$ in relation to the two temporal steps of $\mathrm{G} 1$ is likely important to ensure the proper timing of events including the assembly and recognition of spatial landmarks, and execution of polarity establishment at a single site by organizing the actin and septin cytoskeleton (see Figure 4).

While an understanding of the mechanistic details requires further investigation, it is interesting to note that stepwise activation of $\mathrm{Cdc} 42$ and Rac GTPases has also been observed in other cell types, such as growth factorstimulated endothelial cells and antigen-stimulated mast cells during spatial cue-directed cell polarization [90-92]. Therefore, biphasic activation of a GTPase may be a general mechanism underlying signal-responsive cell polarization.
NEGATIVE POLARITY SIGNALING AND POTENTIAL IMPLICATIONS IN AGING

Cycling of the GTP- and GDP-bound states of Cdc42 is essential for proper cellular function in yeast and animals including humans. Thus, turning off $\mathrm{Cdc} 42$ activity is as important as its activation. Specific cdc42 alleles that express dominant active mutant forms of $\mathrm{Cdc} 42$ cause dosage-dependent lethality in budding yeast [93]. Deletion of Cdc42 GAPs (rga1 1 rga2 $\Delta$ bem $3 \Delta$ ), which leads to elevated levels of active Cdc42-GTP, also causes defects in septin organization and polarized growth in yeast, suggesting that GTP hydrolysis by $\mathrm{Cdc} 42$ is essential for its function $[60,88$, 94].

Negative regulation of $\mathrm{Cdc} 42$ is also involved in selecting a new bud site. Both haploid and diploid cells select a new bud site that does not overlap with the previous bud site $[95,96]$. Indeed, an elegant study showed that Rga1 plays a critical role in inactivating $\mathrm{Cdc} 42$ at the division site and thus blocks repolarization of $\mathrm{Cdc} 42$ within that site [44]. This distinct role of Rga1 in fine-tuning bud-site selection is not shared with other Cdc42 GAPs in haploid and diploid cells $[44,97]$. Another negative regulator of $\mathrm{Cdc} 42$ signaling is Gps1 [98] (also known as Aim44, whose deficiency alters mitochondrial biogenesis and inheritance [99]). Gps1 establishes a novel polarity cue that sustains Rho1-dependent polarization but inhibits premature Cdc42-dependent activation of the PAK Cla4 at the site of cytokinesis [98]. Genetic analyses suggest that Gps1 may work in parallel with Rga1 to inhibit Cdc42 repolarization at the current division site [98]. These studies, however, did not answer why all old bud sites (other than the immediately preceding division site) are excluded from subsequent divisions.

All cell division sites are decorated with chitin-rich bud scars, which contain 'cytokinesis remnants (CRM)' including Rax1 and Rax2, two interdependent transmembrane proteins. Rax1 and Rax2 localize to the distal pole (in daughter cells) as well as the division site after septation and stably remain at the site during multiple generations $[100,101]$. Interestingly, while Gps1 does not localize to CRMs, it recruits $\mathrm{Nba1}$ and Nis1, a negative polarity complex that antagonizes Cdc42 activation, at the current division site. Nba1 and Nis1 are subsequently inherited to CRMs and stably anchored via interaction with Rax1/Rax2 [34]. This negative polarity cue has been suggested to inhibit Cdc42 at CRMs by interfering with the interaction between Cdc24 and Rsr1 and thus locally preventing activation of Cdc24 [34]. However, this mechanism is debatable because neither Cdc24 nor Rsr1 localizes to CRMs. On the other hand, Rga1 localizes not only to the current cell division site but also to CRMs transiently $[46,49]$ via its direct interaction with Nba1 [49]. Genetic analyses also confirmed that Rga1 functions together with Nba1 and Nis1, rather than in parallel, in preventing re-budding within the current and all previous division sites [49]. Therefore, the inhibitory function of the negative polarity cues at CRMs is likely due to the GAP activity of Rga1, reinforcing 
the idea that Rga1 activity prevents re-use of any previous division site for yeast budding (Figure 5).

Remarkably, yeast cells lacking negative polarity cues display nuclear segregation defects and a decreased RLS [34]. These observations led to a proposal that cytokinesis remnants act as 'cellular memory' for previous polarization events, and that negative polarity cues keep Cdc42 inactive at CRMs for proper asymmetric division [34]. The diameter of the bud neck region where nuclear segregation occurs is narrower in rga1s nba1s single or double mutant cells due to repeated re-budding at the same site. This abnormality has been attributed to the cause of impaired nuclear segregation and reduced lifespan in these mutants [34]. However, deletions of other Cdc42 GAPs (rga2 $\Delta$ or bem $3 \Delta$ ) also display significantly reduced RLS than WT, even though their deletions do not have the same phenotypes as rga1 (PJK, unpublished). Thus, an enticing interpretation of these observations is that an increase in Cdc42 activity due to deletion of a Cdc42 GAP may contribute to cellular aging.

Cdc42 activity has been implicated in aging in other cell types. Notably, Cdc42 activity is substantially increased in hematopoietic stem cells as well as in other tissues from aged mice compared to those taken from young mice. This increased Cdc42 activity correlates with the depolarized phenotype and aging of hematopoietic stem cells [102]. Young hematopoietic stem cells divide mainly asymmetrically, whereas aged hematopoietic stem cells divide primarily symmetrically [103], as also observed in old yeast mother cells [33]. This mode of cell division is tightly linked to stem cell polarity and is regulated by the activity level of Cdc42 [103]. Large-scale data analyses and modeling have also found a correlation between CDC42 upregulation in human white blood cells and aging as well as association of increased expression of CDC42 with higher mortality [104]. Additionally, mice deficient for the p50RhoGAP protein, in which Cdc42 activity is increased in all tissues, present with premature aging-like phenotypes [105]. Interestingly, treatment of aged hematopoietic stem cells with a Cdc42 activity inhibitor (CASIN) reduced the level of Cdc42 activity to that of young cells and rejuvenated aged hematopoietic stem cells [102]. These studies raise a number of questions regarding the development of aging and reveal the intriguing possibility that negative regulation of $\mathrm{Cdc} 42$ is critical in aged cells as in young cells. While the connection between Cdc42 activity and aging is a tantalizing possibility, further investigation is necessary to reveal a concrete role of Cdc42 signaling in aging.

\section{CONCLUDING REMARKS}

Cell polarity is a nearly universal feature that arises in almost all species ranging from bacteria to human and is fundamental to asymmetric cell division, growth, and development. Despite substantial progress in deciphering the mechanisms underlying $\mathrm{Cdc} 42$ polarization in budding yeast, significant gaps exist in our current knowledge of cell polarization. In particular, we are only beginning to understand how multiple processes leading to bud emergence, including actin and septin cytoskeleton organization and polarized secretion, are temporally coordinated. Another critical question is why budding yeast maintain such an elaborate program of polarized growth. Although a number of ideas have been suggested, it has not been directly addressed why this single-cell organism undergoes such complex oriented cell division as seen in developing embryos, which need a distinct body plan. To fully understand how yeast cells integrate multiple signals and why such a genetic program has evolved may benefit from both experimental and theoretical efforts. Further studies are required to understand the causative relationship of numerous changes associated with aging and the role of $\mathrm{Cdc} 42$ signaling. A deeper understanding of spatial and temporal regulation of Cdc42 activity in young and aged cells is undoubtably significant and may also lead to identification of key pharmacological targets for turning back the clock on aging.
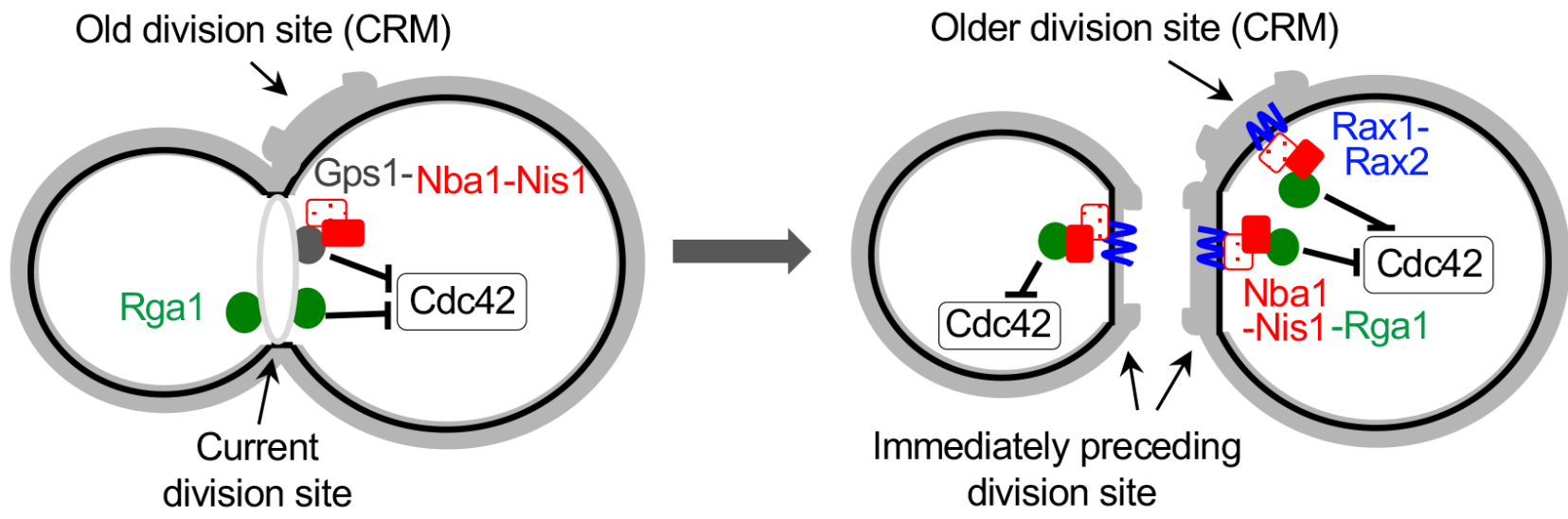

FIGURE 5: Model for inhibition of Cdc42 at the current and old cell division sites by negative polarity cues. During cytokinesis, Rga1 (green) and the Nba1-Nis1-Gps1 complex inhibit Cdc42 repolarization to the division site. After cytokinesis and septum formation, the Nba1-Nis1 complex (red) are inherited to the immediately preceding division site and remain at the older division sites (CRMs) via interaction with Rax1/Rax2 (blue lines). Rga1 also localizes transiently to CRMs via interaction with Nba1-Nis1 and inhibits Cdc42 repolarization at CRMs. The complex at the old division site is omitted in the cell shown on the left. Taken from Ref. [49]. 


\section{ACKNOWLEDGMENTS}

We are grateful to the members of the Park laboratory for discussion and comments on the manuscript. We apologize to colleagues for not citing all relevant work due to space limitation of this short review. Our research has been supported by grants from the National Institutes of Health/National Institute of General Medical Sciences (R01-GM114582) and the National Institutes of Health/National Institute on Aging (R21AG060028) to H.-O. P.

\section{CONFLICT OF INTEREST}

The authors declare no conflict of interest.

\section{REFERENCES}

1. Drubin DG, Nelson WJ (1996). Origins of cell polarity. Cell 84(3): 335-344. doi: 10.1016/s0092-8674(00)81278-7

2. Nelson WJ (2003). Adaptation of core mechanisms to generate cell polarity. Nature 422(6978): 766 - 774. doi: 10.1038/nature01602

3. Etienne-Manneville S (2004). Cdc42 - the centre of polarity. J Cell Sci 117(Pt 8): 1291-1300. doi: 10.1242/jcs.01115

4. Park H-O, Bi E (2007). Central roles of small GTPases in the development of cell polarity in yeast and beyond. Microbiol Mol Biol Rev 71(1): 48-96. doi: 10.1128/MMBR.00028-06

5. Svensmark JH, Brakebusch C (2019). Rho GTPases in cancer: friend or foe? Oncogene 38(50): 7447-7456. doi: 10.1038/s41388-019-0963-

6. Reymond N, Im JH, Garg R, Vega FM, Borda d'Agua B, Riou P, Cox S, Valderrama F, Muschel RJ, Ridley AJ (2012). Cdc42 promotes transendothelial migration of cancer cells through beta1 integrin. J Cell Biol 199(4): 653-668. doi: 10.1083/jcb.201205169

7. Geiger $\mathrm{H}$, Zheng $Y$ (2013). Cdc42 and aging of hematopoietic stem cells. Curr Opin Hematol 20(4): 295-300. doi: 10.1097/MOH.0b013e3283615aba

8. Freifelder D (1960). Bud position in Saccharomyces cerevisiae. J Bacteriol 80:567-568. doi: 10.1128/jb.80.4.567-568.1960

9. Hicks JB, Strathern JN, Herskowitz I (1977). Interconversion of yeast mating types III. Action of the homothallism $(\mathrm{HO})$ gene in cells homozygous for the mating type locus. Genetics 85(3): 395-405. PMID: 17248736

10. Chant J, Pringle JR (1995). Patterns of bud-site selection in the yeast Saccharomyces cerevisiae. J Cell Biol 129(3): 751-765. doi: 10.1083/jcb.129.3.751

11. Bender A, Pringle JR (1989). Multicopy suppression of the $c d c 24$ budding defect in yeast by $C D C 42$ and three newly identified genes including the ras-related gene RSR1. Proc Natl Acad Sci USA 86(24): 9976-9980. doi: 10.1073/pnas.86.24.9976

12. Bender A (1993). Genetic evidence for the roles of the bud-siteselection genes BUD5 and BUD2 in control of the Rsr1p (Bud1p) GTPase in yeast. Proc Natl Acad Sci, U S A 90(21): 9926-9929. doi: 10.1073/pnas.90.21.9926

13. Chant J, Corrado K, Pringle JR, Herskowitz I (1991). Yeast BUD5, encoding a putative GDP-GTP exchange factor, is necessary for bud site selection and interacts with bud formation gene BEM1. Cell 65(7): 1213-1224. doi: 10.1016/0092-8674(91)90016-r

14. Chant J, Herskowitz I (1991). Genetic control of bud site selection in yeast by a set of gene products that constitute a morphogenetic pathway. Cell 65(7): 1203-1212. doi: 10.1016/0092-8674(91)90015-q

\section{COPYRIGHT}

(C) 2020 Miller et al. This is an open-access article released under the terms of the Creative Commons Attribution (CC BY) license, which allows the unrestricted use, distribution, and reproduction in any medium, provided the original author and source are acknowledged.

Please cite this article as: Kristi E. Miller, Pil Jung Kang and HayOak Park (2020). Regulation of Cdc42 for polarized growth in budding yeast. Microbial Cell 7(7): 175-189. doi: 10.15698/mic2020.07.722

15. Park H-O, Chant J, Herskowitz I (1993). BUD2 encodes a GTPaseactivating protein for Bud1/Rsr1 necessary for proper bud-site selection in yeast. Nature 365(6443): 269-274. doi: 10.1038/365269a0

16. Zheng $Y$, Bender A, Cerione RA (1995). Interactions among proteins involved in bud-site selection and bud-site assembly in Saccharomyces cerevisiae. J Biol Chem 270(2): 626-630. doi: 10.1074/jbc. 270.2 .626

17. Park H-O, Bi E, Pringle JR, Herskowitz I (1997). Two active states of the Ras-related Bud1/Rsr1 protein bind to different effectors to determine yeast cell polarity. Proc Natl Acad Sci USA 94(9): 44634468. doi: 10.1073/pnas.94.9.4463

18. Kozminski KG, Beven L, Angerman E, Tong AHY, Boone C, Park H-O (2003). Interaction between a Ras and a Rho GTPase couples selection of a growth site to the development of cell polarity in yeast. Mol Biol Cell 14(12): 4958-4970. doi: 10.1091/mbc.e03-06-0426

19. Shimada $Y$, Wiget $P$, Gulli MP, Bi E, Peter $M$ (2004). The nucleotide exchange factor Cdc24p may be regulated by auto-inhibition. EMBO J 23(5): 1051-1062. doi: 10.1038/sj.emboj.7600124

20. Kang PJ, Beven L, Hariharan S, Park H-O (2010). The Rsr1/Bud1 GTPase Interacts with Itself and the Cdc42 GTPase during Bud-Site Selection and Polarity Establishment in Budding Yeast. Mol Biol Cell 21(17): 3007-3016. doi: 10.1091/mbc.E10-03-0232

21. Miller KE, Lo WC, Chou CS, Park HO (2019). Temporal regulation of cell polarity via the interaction of the Ras GTPase Rsr1 and the scaffold protein Bem1. Mol Biol Cell 30(20): 2543-2557. doi: 10.1091/mbc.E19-02-0106

22. Hartwell LH, Culotti J, Pringle JR, Reid BJ (1974). Genetic control of the cell division cycle in yeast. Science 183(4120): 46-51. doi: 10.1126/science.183.4120.46

23. Charvin G, Oikonomou C, Siggia ED, Cross FR (2010). Origin of Irreversibility of Cell Cycle Start in Budding Yeast. PLoS Biol 8(1): e1000284. doi: 10.1371/journal.pbio.1000284

24. Doncic A, Falleur-Fettig $M$, Skotheim JM (2011). Distinct interactions select and maintain a specific cell fate. Mol Cell 43(4): 528-539. doi: 10.1016/j.molcel.2011.06.025

25. Di Talia S, Skotheim JM, Bean JM, Siggia ED, Cross FR (2007). The effects of molecular noise and size control on variability in the budding yeast cell cycle. Nature 448(7156): 947-951. doi: $10.1038 /$ nature06072

26. Costanzo M, Nishikawa JL, Tang X, Millman JS, Schub O, Breitkreuz K, Dewar D, Rupes I, Andrews B, Tyers M (2004). CDK activity antagonizes Whi5, an inhibitor of G1/S transcription in yeast. Cell 117(7): 899-913. doi: 10.1016/j.cell.2004.05.024 
27. Skotheim JM, Di Talia S, Siggia ED, Cross FR (2008). Positive feedback of G1 cyclins ensures coherent cell cycle entry. Nature 454(7202): 291-296. doi: 10.1038/nature07118

28. Slaughter BD, Smith SE, Li R (2009). Symmetry breaking in the life cycle of the budding yeast. Cold Spring Harb Perspect Biol 1(3): a003384. doi: 10.1101/cshperspect.a003384

29. Martin SG (2015). Spontaneous cell polarization: Feedback control of Cdc42 GTPase breaks cellular symmetry. Bioessays 37(11): 11931201. doi: 10.1002/bies.201500077

30. Chiou JG, Balasubramanian MK, Lew DJ (2017). Cell Polarity in Yeast. Annu Rev Cell Dev Biol 33: 77-101. doi: 10.1146/annurevcellbio-100616-060856

31. Goryachev AB, Leda M (2017). Many roads to symmetry breaking: molecular mechanisms and theoretical models of yeast cell polarity. Mol Biol Cell 28(3): 370-380. doi: 10.1091/mbc.E16-10-0739

32. Jazwinski SM, Egilmez NK, Chen JB (1989). Replication control and cellular life span. Exp Gerontol 24(5-6): 423-436. doi: 10.1016/05315565(89)90049-1

33. Kennedy BK, Austriaco NR, Jr., Guarente L (1994). Daughter cells of Saccharomyces cerevisiae from old mothers display a reduced life span. J Cell Biol 127(6 Pt 2): 1985-1993. doi: 10.1083/jcb.127.6.1985

34. Meitinger F, Khmelinskii A, Morlot S, Kurtulmus B, Palani S, Andres-Pons A, Hub B, Knop M, Charvin G, Pereira G (2014). A memory system of negative polarity cues prevents replicative aging. Cell 159(5): 1056-1069. doi: 10.1016/j.cell.2014.10.014

35. Ruan L, Zhang X, Li R (2018). Recent insights into the cellular and molecular determinants of aging. J Cell Sci 131(3). doi: $10.1242 /$ jcs. 210831

36. Bi E, Park H-O (2012). Cell polarization and cytokinesis in budding yeast. Genetics 191(2): 347-387. doi: 10.1534/genetics.111.132886

37. Kang PJ, Lee ME, Park H-O (2014). Bud3 activates Cdc42 to establish a proper growth site in budding yeast. J Cell Biol 206(1): 1928. doi: $10.1083 /$ jcb. 201402040

38. Schmidt A, Hall A (2002). Guanine nucleotide exchange factors for Rho GTPases: turning on the switch. Genes Dev 16(13): 1587-1609 doi: 10.1101/gad.1003302

39. Zheng $Y$, Cerione R, Bender A (1994). Control of the yeast bud-site assembly GTPase Cdc42: catalysis of guanine nucleotide exchange by Cdc24 and stimulation of GTPase activity by Bem3. J Biol Chem 269(4): 2369-2372. PMID: 8300560

40. Chant J, Mischke M, Mitchell E, Herskowitz I, Pringle JR (1995). Role of Bud3p in producing the axial budding pattern of yeast. J Cell Biol 129(3): 767-778. doi: 10.1083/jcb.129.3.767

41. Nern A, Arkowitz RA (2000). Nucleocytoplasmic shuttling of the Cdc42p exchange factor Cdc24p. J Cell Biol 148(6): 1115-1122. doi: 10.1083/jcb.148.6.1115

42. Shimada Y, Gulli M-P, Peter M (2000). Nuclear sequestration of the exchange factor Cdc24p by Far1 regulates cell polarity during mating. Nat Cell Biol 2(2): 117-124. doi: 10.1038/35000073

43. Ozbudak EM, Becskei A, van Oudenaarden A (2005). A system of counteracting feedback loops regulates Cdc42p activity during spontaneous cell polarization. Dev Cell 9(4): 565-571. doi: 10.1016/j.devcel.2005.08.014

44. Tong Z, Gao XD, Howell AS, Bose I, Lew DJ, Bi E (2007). Adjacent positioning of cellular structures enabled by a Cdc42 GTPaseactivating protein-mediated zone of inhibition. J Cell Biol 179(7): 1375-1384. doi: 10.1083/jcb.200705160
45. Okada S, Lee ME, Bi E, Park H-O (2017). Probing Cdc42 Polarization Dynamics in Budding Yeast Using a Biosensor. Methods Enzymol 589: 171-190. doi: 10.1016/bs.mie.2017.01.011

46. Lee ME, Lo WC, Miller KE, Chou CS, Park H-O (2015). Regulation of Cdc42 polarization by the Rsr1 GTPase and Rga1, a Cdc42 GTPaseactivating protein, in budding yeast. J Cell Sci 128(11): 2106-2117. doi: 10.1242/jcs.166538

47. Das M, Drake T, Wiley DJ, Buchwald P, Vavylonis D, Verde F (2012). Oscillatory dynamics of Cdc42 GTPase in the control of polarized growth. Science 337(6091): 239-243. doi: 10.1126/science.1218377

48. Novák B, Tyson JJ (2008). Design principles of biochemical oscillators. Nat Rev Mol Cell Biol 9(12): 981-991. doi: 10.1038/nrm2530

49. Miller KE, Lo WC, Lee ME, Kang PJ, Park H-O (2017). Fine-tuning the orientation of the polarity axis by Rga1, a Cdc42 GTPase-activating protein. Mol Biol Cell 28(26): 3773-3788. doi: 10.1091/mbc.E17-010074

50. Hwang JU, Gu Y, Lee YJ, Yang Z (2005). Oscillatory ROP GTPase activation leads the oscillatory polarized growth of pollen tubes. Mol Biol Cell 16(11): 5385-5399. doi: 10.1091/mbc.e05-05-0409

51. Carlin LM, Evans R, Milewicz H, Fernandes L, Matthews DR, Perani M, Levitt J, Keppler MD, Monypenny J, Coolen T, Barber PR, Vojnovic B, Suhling K, Fraternali F, Ameer-Beg S, Parker PJ, Thomas NS, Ng T (2011). A targeted siRNA screen identifies regulators of Cdc42 activity at the natural killer cell immunological synapse. Sci Signal 4(201): ra81. doi: 10.1126/scisignal.2001729

52. Howell AS, Jin M, Wu CF, Zyla TR, Elston TC, Lew DJ (2012). Negative feedback enhances robustness in the yeast polarity establishment circuit. Cell 149(2): 322-333. doi: 10.1016/j.cell.2012.03.012

53. Kuo CC, Savage NS, Chen H, Wu CF, Zyla TR, Lew DJ (2014). Inhibitory GEF Phosphorylation Provides Negative Feedback in the Yeast Polarity Circuit. Curr Biol 24(7): 753-759. doi: 10.1016/j.cub.2014.02.024

54. Toenjes KA, Sawyer MM, Johnson DI (1999). The guaninenucleotide-exchange factor Cdc24p is targeted to the nucleus and polarized growth sites. Curr Biol 9(20): 1183-1186. doi: 10.1016/S0960-9822(00)80022-6

55. Albuquerque CP, Smolka MB, Payne SH, Bafna V, Eng J, Zhou H (2008). A multidimensional chromatography technology for in-depth phosphoproteome analysis. Mol Cell Proteomics 7(7): 1389-1396. doi: 10.1074/mcp.M700468-MCP200

56. Holt L, Tuch BB, Villen J, Johnson AD, Gygi SP, Morgan DO (2009). Global analysis of Cdk1 substrate phosphorylation sites provides insights into evolution. Science 325(5948): 1682-1686. doi: 10.1126/science.1172867

57. Swaney DL, Beltrao P, Starita L, Guo A, Rush J, Fields S, Krogan NJ, Villen $J$ (2013). Global analysis of phosphorylation and ubiquitylation cross-talk in protein degradation. Nature methods 10(7): 676-682. doi: $10.1038 /$ nmeth. 2519

58. Stevenson BJ, Ferguson B, De Virgilio C, Bi E, Pringle JR, Ammerer G, Sprague GFJ (1995). Mutation of RGA1, which encodes a putative GTPase-activating protein for the polarity-establishment protein Cdc42p, activates the pheromone-response pathway in the yeast Saccharomyces cerevisiae. Genes Dev 9(23): 2949-2963. doi: 10.1101/gad.9.23.2949

59. Chen GC, Zheng L, Chan CS (1996). The LIM domain-containing Dbm1 GTPase-activating protein is required for normal cellular morphogenesis in Saccharomyces cerevisiae. Mol Cell Biol 16(4): 1376-1390. doi: 10.1128/mcb.16.4.1376 
60. Smith GR, Givan SA, Cullen P, Sprague GF, Jr. (2002). GTPaseactivating proteins for Cdc42. Eukaryot Cell 1(3): 469-480. doi: 10.1128/ec.1.3.469-480.2002

61. Kang PJ, Miller KE, Guegueniat J, Beven L, Park H-O (2018). The shared role of the Rsr1 GTPase and Gic1/Gic2 in Cdc42 polarization. Mol Biol Cell 29(20): 2359-2369. doi: 10.1091/mbc.E18-02-0145

62. Kawasaki R, Fujimura-Kamada K, Toi H, Kato H, Tanaka K (2003). The upstream regulator, Rsr1p, and downstream effector, Gic1p and Gic2p, of the Cdc42p small GTPase coordinately regulate initiation of budding in Saccharomyces cerevisiae. Genes Cells 8(3): 235-250. doi: 10.1046/j.1365-2443.2003.00629.x

63. Witte K, Strickland D, Glotzer M (2017). Cell cycle entry triggers a switch between two modes of $\mathrm{Cdc} 42$ activation during yeast polarization. elife 6: e26722. doi: 10.7554/eLife.26722

64. Liu D, Novick $P$ (2014). Bem1p contributes to secretory pathway polarization through a direct interaction with Exo70p. J Cell Biol 207(1): 59-72. doi: 10.1083/jcb.201404122

65. Moran KD, Kang H, Araujo AV, Zyla TR, Saito K, Tsygankov D, Lew DJ (2019). Cell-cycle control of cell polarity in yeast. J Cell Biol 218(1): 171-189. doi: 10.1083/jcb.201806196

66. Henchoz S, Chi Y, Catarin B, Herskowitz I, Deshaies RJ, Peter M (1997). Phosphorylation- and ubiquitin-dependent degradation of the cyclin-dependent kinase inhibitor Far1p in budding yeast. Genes Dev 11(22): 3046-3060. doi: 10.1101/gad.11.22.3046

67. Park H-O, Kang PJ, Rachfal AW (2002). Localization of the Rsr1/Bud1 GTPase involved in selection of a proper growth site in yeast. J Biol Chem 277(30): 26721-26724. doi: 10.1074/jbc.C200245200

68. Irazoqui JE, Gladfelter AS, Lew DJ (2003). Scaffold-mediated symmetry breaking by Cdc42p. Nat Cell Biol 5(12): 1062-1070. doi: 10.1038/ncb1068

69. Wedlich-Soldner R, Wai SC, Schmidt T, Li R (2004). Robust cell polarity is a dynamic state established by coupling transport and GTPase signaling. J Cell Biol 166(6): 889-900. doi: 10.1083/jcb.200405061

70. Kozubowski L, Saito K, Johnson JM, Howell AS, Zyla TR, Lew DJ (2008). Symmetry-breaking polarization driven by a Cdc42p GEF-PAK complex. Curr Biol 18(22): 1719-1726. doi: 10.1016/j.cub.2008.09.060

71. Smith SE, Rubinstein B, Mendes Pinto I, Slaughter BD, Unruh JR, Li $R$ (2013). Independence of symmetry breaking on Bem1-mediated autocatalytic activation of Cdc42. J Cell Biol 202(7): 1091-1106. doi: 10.1083/jcb.201304180

72. Rapali P, Mitteau R, Braun C, Massoni-Laporte A, Unlu C, Bataille L, Arramon FS, Gygi SP, McCusker D (2017). Scaffold-mediated gating of Cdc42 signalling flux. eLife 6: e25257. doi: 10.7554/eLife. 25257

73. Wedlich-Soldner R, Altschler S, Wu L, Li R (2003). Spontaneous cell polarization through actomyosin-based delivery of the Cdc42 GTPase. Science 299(5610): 1231-1235. doi: 10.1126/science.1080944

74. Marco E, Wedlich-Soldner R, Li R, Altschuler SJ, Wu LF (2007). Endocytosis optimizes the dynamic localization of membrane proteins that regulate cortical polarity. Cell 129(2): 411-422. doi: 10.1016/j.cell.2007.02.043

75. Slaughter BD, Das A, Schwartz JW, Rubinstein B, Li R (2009). Dual modes of cdc42 recycling fine-tune polarized morphogenesis. Dev Cell 17(6): 823-835. doi: 10.1016/j.devcel.2009.10.022

76. Freisinger T, Klunder B, Johnson J, Muller N, Pichler G, Beck G, Costanzo M, Boone C, Cerione RA, Frey E, Wedlich-Soldner R (2013). Establishment of a robust single axis of cell polarity by coupling multiple positive feedback loops. Nat Commun 4(1807): 1807. doi: 10.1038/ncomms2795
77. Woods B, Lai H, Wu CF, Zyla TR, Savage NS, Lew DJ (2016). Parallel Actin-Independent Recycling Pathways Polarize Cdc42 in Budding Yeast. Curr Biol 26(16): 2114-2126. doi: 10.1016/j.cub.2016.06.047

78. Howell AS, Savage NS, Johnson SA, Bose I, Wagner AW, Zyla TR, Nijhout HF, Reed MC, Goryachev AB, Lew DJ (2009). Singularity in polarization: rewiring yeast cells to make two buds. Cell 139(4): 731743. doi: 10.1016/j.cell.2009.10.024

79. Savage NS, Layton AT, Lew DJ (2012). Mechanistic mathematical model of polarity in yeast. Mol Biol Cell 23(10): 1998-2013. doi: 10.1091/mbc.E11-10-0837

80. Layton AT, Savage NS, Howell AS, Carroll SY, Drubin DG, Lew DJ (2011). Modeling vesicle traffic reveals unexpected consequences for Cdc42p-mediated polarity establishment. Curr Biol 21(3): 184-194 doi: 10.1016/j.cub.2011.01.012

81. Watson LJ, Rossi G, Brennwald P (2014). Quantitative analysis of membrane trafficking in regulation of Cdc42 polarity. Traffic 15(12): 1330-1343. doi: 10.1111/tra.12211

82. Jose M, Tollis S, Nair D, Sibarita JB, McCusker D (2013). Robust polarity establishment occurs via an endocytosis-based cortical corralling mechanism. J Cell Biol 200(4): 407-418. doi: 10.1083/jcb.201206081

83. Bendezu FO, Vincenzetti V, Vavylonis D, Wyss R, Vogel H, Martin SG (2015). Spontaneous Cdc42 polarization independent of GDImediated extraction and actin-based trafficking. PLoS Biol 13(4): e1002097. doi: 10.1371/journal.pbio.1002097

84. Sanders SL, Herskowitz | (1996). The Bud4 protein of yeast, required for axial budding, is localized to the mother/bud neck in a cell cycle-dependent manner. J Cell Biol 134(2): 413-427. doi: 10.1083/jcb.134.2.413

85. Kang PJ, Angerman E, Jung $\mathrm{CH}$, Park H-O (2012). Bud4 mediates the cell-type-specific assembly of the axial landmark in budding yeast. J Cell Sci 125(Pt 16): 3840-3849. doi: 10.1242/jcs.103697

86. Kang PJ, Sanson A, Lee B, Park H-O (2001). A GDP/GTP exchange factor involved in linking a spatial landmark to cell polarity. Science 292(5520): 1376-1378. doi: 10.1126/science.1060360

87. Iwase M, Luo J, Nagaraj S, Longtine M, Kim HB, Haarer BK, Caruso C, Tong Z, Pringle JR, Bi E (2006). Role of a Cdc42p effector pathway in recruitment of the yeast septins to the presumptive bud site. Mol Biol Cell 17(3): 1110-1125. doi: 10.1091/mbc.e05-08-0793

88. Gladfelter AS, Bose I, Zyla TR, Bardes ESG, Lew DJ (2002). Septin ring assembly involves cycles of GTP loading and hydrolysis by Cdc42p. J Cell Biol 156(2): 315-326. doi: 10.1083/jcb.200109062

89. Okada S, Leda M, Hanna J, Savage NS, Bi E, Goryachev AB (2013). Daughter cell identity emerges from the interplay of Cdc42, septins, and exocytosis. Dev Cell 26(2): 148-161. doi: 10.1016/j.devcel.2013.06.015

90. El-Sibai M, Backer JM (2007). Phospholipase C gamma negatively regulates Rac/Cdc42 activation in antigen-stimulated mast cells. Eur J Immunol 37(1): 261-270. doi: 10.1002/eji.200635875

91. Garrett TA, Van Buul JD, Burridge K (2007). VEGF-induced Rac1 activation in endothelial cells is regulated by the guanine nucleotide exchange factor Vav2. Exp Cell Res 313(15): 3285-3297. doi: 10.1016/j.yexcr.2007.05.027

92. Kobayashi H, Ogura Y, Sawada M, Nakayama R, Takano K, Minato $Y$, Takemoto $Y$, Tashiro E, Watanabe $H$, Imoto $M$ (2011). Involvement of 14-3-3 proteins in the second epidermal growth factor-induced wave of Rac1 activation in the process of cell migration. J Biol Chem 286(45): 39259-39268. doi: 10.1074/jbc.M111.255489

93. Ziman M, O'Brien JM, Ouellette LA, Church WR, Johnson DI (1991). Mutational analysis of CDC42Sc, a Saccharomyces cerevisiae gene that 
encodes a putative GTP-binding protein involved in the control of cell polarity. Mol Cell Biol 11(7): 3537-3544. doi: 10.1128/mcb.11.7.3537

94. Caviston JP, Longtine M, Pringle JR, Bi E (2003). The role of Cdc42p GTPase-activating proteins in assembly of the septin ring in yeast. Mol Biol Cell 14(10): 4051-4066. doi: 10.1091/mbc.e03-04-0247

95. Barton AA (1950). Some aspects of cell division in saccharomyces cerevisiae. J Gen Microbiol 4(1): 84-86. doi: 10.1099/00221287-4-1-84

96. Mortimer RK, Johnston JR (1959). Life span of individual yeast cells. Nature 183(4677): 1751-1752. doi: 10.1038/1831751a0

97. Lo WC, Lee ME, Narayan M, Chou CS, Park H-O (2013). Polarization of diploid daughter cells directed by spatial cues and GTP hydrolysis of Cdc42 budding yeast. PLoS One 8(2): e56665. doi: 10.1371/journal.pone.0056665

98. Meitinger F, Richter H, Heisel S, Hub B, Seufert W, Pereira G (2013). A safeguard mechanism regulates Rho GTPases to coordinate cytokinesis with the establishment of cell polarity. PLoS Biol 11(2): e1001495. doi: 10.1371/journal.pbio.1001495

99. Hess DC, Myers CL, Huttenhower C, Hibbs MA, Hayes AP, Paw J, Clore JJ, Mendoza RM, Luis BS, Nislow C, Giaever G, Costanzo M, Troyanskaya OG, Caudy AA (2009). Computationally driven, quantitative experiments discover genes required for mitochondrial biogenesis. PLoS Genet 5(3): e1000407. doi: 10.1371/journal.pgen.1000407

100. Chen T, Hiroko T, Chaudhuri A, Inose F, Lord M, Tanaka S, Chant J, Fujita A (2000). Multigenerational cortical inheritance of the Rax2 protein in orienting polarity and division in yeast. Science $290(5498)$ : 1975-1978. doi: 10.1126/science.290.5498.1975

101. Kang PJ, Angerman E, Nakashima K, Pringle JR, Park H-O (2004). Interactions among Rax1p, Rax2p, Bud8p, and Bud9p in marking cortical sites for bipolar bud-site selection in yeast. Mol Biol Cell 15(11): 5145-5157. doi: 10.1091/mbc.e04-07-0600

102. Florian MC, Dorr K, Niebel A, Daria D, Schrezenmeier H, Rojewski M, Filippi MD, Hasenberg A, Gunzer M, Scharffetter-Kochanek K, Zheng $Y$, Geiger $H$ (2012). Cdc42 activity regulates hematopoietic stem cell aging and rejuvenation. Cell Stem Cell 10(5): 520-530. doi: 10.1016/j.stem.2012.04.007

103. Florian MC, Klose M, Sacma M, Jablanovic J, Knudson L, Nattamai KJ, Marka G, Vollmer A, Soller K, Sakk V, Cabezas-Wallscheid N, Zheng $Y$, Mulaw MA, Glauche I, Geiger H (2018). Aging alters the epigenetic asymmetry of HSC division. PLoS Biol 16(9): e2003389. doi: 10.1371/journal.pbio.2003389

104. Kerber RA, O'Brien E, Cawthon RM (2009). Gene expression profiles associated with aging and mortality in humans. Aging Cell 8(3): 239-250. doi: 10.1111/j.1474-9726.2009.00467.x

105. Wang L, Yang L, Debidda M, Witte D, Zheng Y (2007). Cdc42 GTPase-activating protein deficiency promotes genomic instability and premature aging-like phenotypes. Proc Natl Acad Sci USA 104(4): 1248-1253. doi: 10.1073/pnas.0609149104

106. Adams AE, Johnson DI, Longnecker RM, Sloat BF, Pringle JR (1990). CDC42 and CDC43, two additional genes involved in budding and the establishment of cell polarity in the yeast Saccharomyces cerevisiae. J Cell Biol 111(1): 131-142. doi: 10.1083/jcb.111.1.131

107. Johnson DI, Pringle JR (1990). Molecular characterization of CDC42, a Saccharomyces cerevisiae gene involved in the development of cell polarity. J Cell Biol 111(1): 143-152. doi: 10.1083/jcb.111.1.143

108. Sartorel E, Unlu C, Jose M, Massoni-Laporte A, Meca J, Sibarita JB, McCusker D (2018). Phosphatidylserine and GTPase activation control Cdc42 nanoclustering to counter dissipative diffusion. Mol Biol Cell 29(11): 1299-1310. doi: 10.1091/mbc.E18-01-0051
109. Meca J, Massoni-Laporte A, Martinez D, Sartorel E, Loquet A, Habenstein B, McCusker D (2019). Avidity-driven polarity establishment via multivalent lipid-GTPase module interactions. EMBO J 38(3): e99652. doi: 10.15252/embj.201899652

110. Sloat B, Adams A, Pringle JR (1981). Roles of the CDC24 gene product in cellular morphogenesis during the Saccharomyces cerevisiae cell cycle. J Cell Biol 89(3):395-405. doi: 10.1083/jcb.89.3.395

111. Nern A, Arkowitz RA (1998). A GTP-exchange factor required for cell orientation. Nature 391(6663):195-198. doi: 10.1038/34458

112. Nern A, Arkowitz RA (1999). A Cdc24p-Far1p-Gbetagamma protein complex required for yeast orientation during mating. J Cell Biol 144(6):1187-1202. doi: 10.1083/jcb.144.6.1187

113. Gulli MP, Jaquenoud $M$, Shimada $Y$, Niederhauser $G$, Wiget $P$, Peter M (2000). Phosphorylation of the Cdc42 exchange factor Cdc24 by the PAK-like kinase Cla4 may regulate polarized growth in yeast. Mol Cell 6(5):1155-1167. doi: 10.1016/s1097-2765(00)00113-1

114. Wiget $P$, Shimada $Y$, Butty AC, Bi E, Peter $M$ (2004). Site-specific regulation of the GEF Cdc24p by the scaffold protein Far1p during yeast mating. EMBO J 23(5):1063-1074. doi: 10.1038/sj.emboj.7600123

115. Mionnet C, Bogliolo S, Arkowitz RA (2008). Oligomerization regulates the localization of $\mathrm{Cdc} 24$, the $\mathrm{Cdc} 42$ activator in Saccharomyces cerevisiae. J Biol Chem 283(25): 17515-17530. doi: 10.1074/jbc.M800305200

116. Lord M, Yang MC, Mischke M, Chant J (2000). Cell cycle programs of gene expression control morphogenetic protein localization. J Cell Biol 151(7):1501-1512. doi: 10.1083/jcb.151.7.1501

117. Chen X, Wang K, Svitkina T, Bi E (2020). Critical Roles of a RhoGEF-Anillin Module in Septin Architectural Remodeling during Cytokinesis. Curr Biol 30(8): 1477-1490.e1473. doi: 10.1016/j.cub.2020.02.023

118. Bender A, Pringle JR (1991). Use of a screen for synthetic lethal and multicopy suppressee mutants to identify two new genes involved in morphogenesis in Saccharomyces cerevisiae. Mol Cell Biol 11(3): 1295-1305. doi: 10.1128/mcb.11.3.1295

119. Kim Y-J, Francisco L, Chen G-C, Marcotte E, Chan CSM (1994) Control of cellular morphogenesis by the Ipl2/Bem2 GTPase-activating protein: Possible role of protein phosphorylation. J Cell Biol 127(5):1381-1394. doi: 10.1083/jcb.127.5.1381

120. Peterson J, Zheng $\mathrm{Y}$, Bender L, Myers A, Cerione R, Bender A (1994). Interactions between the bud emergence proteins Bem1p and Bem2p and Rho-type GTPases in yeast. J Cell Biol 127(5):1395-1406. doi: $10.1083 / j c b .127 .5 .1395$

121. Knaus $M$, Pelli-Gulli M-P, van Drogen $F$, Springer $S$, Jaquenoud $M$, Peter $M$ (2007). Phosphorylation of Bem2p and Bem3p may contribute to local activation of Cdc42p at bud emergence. EMBO J 26(21): 4501-4513. doi: 10.1038/sj.emboj.7601873

122. Sopko R, Huang D, Smith JC, Figeys D, Andrews BJ (2007). Activation of the Cdc42p GTPase by cyclin-dependent protein kinases in budding yeast. EMBO J 26(21): 4487-4500. doi: 10.1038/sj.emboj.7601847

123. Mukherjee D, Sen A, Boettner DR, Fairn GD, Schlam D, Bonilla Valentin FJ, Michael McCaffery J, Hazbun T, Staiger CJ, Grinstein S, Lemmon SK, Claudio Aguilar R (2013). Bem3, a Cdc42 GTPaseactivating protein, traffics to an intracellular compartment and recruits the secretory Rab GTPase Sec4 to endomembranes. J Cell Sci 126(Pt 20): 4560-4571. doi: 10.1242/jcs.117663

124. Masuda T, Tanaka K, Nonaka H, Yamochi W, Maeda A, Takai Y (1994). Molecular cloning and characterization of yeast rho GDP 
dissociation inhibitor. J Biol Chem 269(31):19713-19718. PMID: 8051050

125. Koch G, Tanaka K, Masuda T, Yamochi W, Nonaka H, Takai Y (1997). Association of the Rho family small GTP-binding proteins with Rho GDP dissociation inhibitor (Rho GDI) in Saccharomyces cerevisiae. Oncogene 15(4):417-422. doi: 10.1038/sj.onc.1201194

126. Chenevert J, Corrado K, Bender A, Pringle J, Herskowitz I (1992). $A$ yeast gene (BEM1) necessary for cell polarization whose product contains two SH3 domains. Nature 356(6364):77-79. doi: $10.1038 / 356077 \mathrm{aO}$

127. Bose I, Irazoqui JE, Moskow JJ, Bardes ES, Zyla TR, Lew DJ (2001). Assembly of scaffold-mediated complexes containing Cdc42p, the exchange factor $\mathrm{Cdc} 24 \mathrm{p}$, and the effector $\mathrm{Cla} 4 \mathrm{p}$ required for cell cycleregulated phosphorylation of Cdc24p. J Biol Chem 276(10): 71767186. doi: 10.1074/jbc.M010546200

128. Cvrckova F, De Virgilio C, Manser E, Pringle JR, Nasmyth K (1995). Ste20-like protein kinases are required for normal localization of cell growth and for cytokinesis in budding yeast. Genes Dev 9(15):18171830. doi: 10.1101/gad.9.15.1817

129. Benton BK, Tinkelenberg A, Gonzalez I, Cross FR (1997). Cla4p, a Saccharomyces cerevisiae Cdc42p-activated kinase involved in cytokinesis, is activated at mitosis. Mol Cell Biol 17(9):5067-5076. doi: 10.1128/mcb.17.9.5067

130. Weiss EL, Bishop AC, Shokat KM, Drubin DG (2000). Chemical genetic analysis of the budding-yeast p21-activated kinase Cla4p. Nat Cell Biol 2(10):677 - 685. doi: 10.1038/35036300

131. Leberer E, Dignard D, Harcus D, Thomas DY, Whiteway M (1992). The protein kinase homologue Ste20p is required to link the yeast pheromone response G-protein beta gamma subunits to downstream signalling components. EMBO J 11(13): 4815-4824. doi: 10.1002/j.1460-2075.1992.tb05587.x

132. Peter M, Neiman A, Park H-O, Lohuizen Mv, Herskowitz I (1996). Interaction between the small GTP-binding protein CDC42 and the protein kinase STE20 is necessary for signal transduction in the yeast pheromone pathway. EMBO J 15(24):7046-7059. PMID: 9003780

133. Atkins BD, Yoshida S, Saito K, Wu CF, Lew DJ, Pellman D (2013). Inhibition of Cdc42 during mitotic exit is required for cytokinesis. J Cell Biol 202(2): 231-240. doi: 10.1083/jcb.201301090

134. Chen GC, Kim YJ, Chan CS (1997). The Cdc42 GTPase-associated proteins Gic1 and Gic2 are required for polarized cell growth in Saccharomyces cerevisiae. Genes Dev 11: 2958-2971. doi 10.1101/gad.11.22.2958

135. Brown JL, Jaquenoud M, Gulli MP, Chant J, Peter M (1997). Nove Cdc42-binding proteins Gic1 and Gic2 control cell polarity in yeast. Genes Dev 11(22):2972-2982. doi: 10.1101/gad.11.22.2972

136. Jaquenoud M, Gulli MP, Peter K, Peter M (1998). The Cdc42p effector Gic2p is targeted for ubiquitin-dependent degradation by the SCFGrr1 complex. EMBO J 17(18):5360-5373. doi: 10.1093/emboj/17.18.5360

137. Sadian Y, Gatsogiannis C, Patasi C, Hofnagel O, Goody RS, Farkasovsky M, Raunser S (2013). The role of Cdc42 and Gic1 in the regulation of septin filament formation and dissociation. elife 2: e01085. doi: 10.7554/eLife.01085

138. Meitinger F, Pereira G (2017). The septin-associated kinase Gin4 recruits Gps1 to the site of cell division. Mol Biol Cell 28(7): 883-889. doi: 10.1091/mbc.E16-09-0687

139. Kohno H, Tanaka K, Mino A, Umikawa M, Imamura H, Fujiwara T, Fujita Y, Hotta K, Qadota H, Watanabe T, Ohya Y, Takai Y (1996). Bni1p implicated in cytoskeletal control is a putative target of Rho1p small
GTP binding protein in Saccharomyces cerevisiae. EMBO J 15(22):6060-6068. doi: 10.1002/j.1460-2075.1996.tb00994.x

140. Evangelista M, Blundell K, Longtine MS, Chow CJ, Adames N, Pringle JR, Peter M, Boone $C$ (1997). Bni1p, a yeast formin linking Cdc42p and the actin cytoskeleton during polarized morphogenesis. Science 276(5309): 118-122. doi: 10.1126/science.276.5309.118

141. Lee L, Klee SK, Evangelista M, Boone C, Pellman D (1999). Control of mitotic spindle position by the Saccharomyces cerevisiae formin Bni1p. J Cell Biol 144(5): 947-961. doi: 10.1083/jcb.144.5.947

142. Pruyne D, Evangelista M, Yang C, Bi E, Zigmond S, Bretscher A, Boone $C$ (2002). Role of formins in actin assembly: nucleation and barbed-end association. Science 297(5581):612-615. doi: 10.1126/science.1072309

143. Sagot I, Rodal AA, Moseley J, Goode BL, Pellman D (2002). An actin nucleation mechanism mediated by Bni1 and profilin. Nat Cell Biol 4(8):626-631. doi: 10.1038/ncb834

144. Moseley JB, Goode BL (2005). Differential activities and regulation of Saccharomyces cerevisiae formin proteins Bni1 and Bnr1 by Bud6. J Biol Chem 280(30): 28023-28033. doi: 10.1038/ncb834

145. Liu W, Santiago-Tirado FH, Bretscher A (2012). Yeast formin Bni1p has multiple localization regions that function in polarized growth and spindle orientation. Mol Biol Cell 23(3): 412-422. doi: 10.1091/mbc.E11-07-0631

146. Miao Y, Wong CC, Mennella V, Michelot A, Agard DA, Holt LJ, Yates JR, 3rd, Drubin DG (2013). Cell-cycle regulation of forminmediated actin cable assembly. Proc Natl Acad Sci USA 110(47): E4446-4455. doi: 10.1073/pnas.1314000110

147. Feng Z, Okada S, Cai G, Zhou B, Bi E (2015). Myosinll heavy chain and formin mediate the targeting of myosin essential light chain to the division site before and during cytokinesis. Mol Biol Cell 26(7): 1211-1224. doi: 10.1091/mbc.E14-09-1363

148. TerBush DR, Maurice T, Roth D, Novick P (1996). The Exocyst is a multiprotein complex required for exocytosis in Saccharomyces cerevisiae. EMBO J 15(23): 6483-6494. doi: 10.1002/j.14602075.1996.tb01039.x

149. Robinson NG, Guo L, Imai J, Toh-E A, Matsui Y, Tamanoi F (1999). Rho3 of Saccharomyces cerevisiae, Which Regulates the Actin Cytoskeleton and Exocytosis, Is a GTPase Which Interacts with Myo2 and Exo70. Mol Cell Biol 19(5):3580-3587. doi: 10.1128/mcb.19.5.3580

150. Boyd C, Hughes T, Pypaert M, Novick P (2004). Vesicles carry most exocyst subunits to exocytic sites marked by the remaining two subunits, Sec3p and Exo70p. J Cell Biol 167(5): 889-901. doi: 10.1083/jcb.200408124

151. Fujita A, Oka C, Arikawa Y, Katagai T, Tonouchi A, Kuhara S, Misumi $Y$ (1994). A yeast gene necessary for bud-site selection encodes a protein similar to insulin-degrading enzymes. Nature 372(6506):567-570. doi: 10.1038/372567a0

152. Roemer T, Madden K, Chang J, Snyder M (1996). Selection of axial growth sites in yeast requires AxI2p, a novel plasma membrane glycoprotein. Genes Dev 10(7):777-793. doi: 10.1101/gad.10.7.777

153. Halme A, Michelitch M, Mitchell EL, Chant J (1996). Bud10p directs axial cell polarization in budding yeast and resembles a transmembrane receptor. Curr Biol 6(5):570-579. doi: 10.1016/s09609822(02)00543-2

154. Sanders SL, Gentzsch M, Tanner W, Herskowitz I (1999). Oglycosylation of $A x \mid 2 / B u d 10 p$ by Pmt4p is required for its stability, localization, and function in daughter cells. J Cell Biol 145(6):11771188. doi: 10.1083/jcb.145.6.1177 
155. Lord M, Inose F, Hiroko T, Hata T, Fujita A, Chant J (2002). Subcellular localization of Axl1, the cell type-specific regulator of polarity. Curr Biol 12(15):1347-1352. doi: 10.1016/s09609822(02)01042-4

156. Gao XD, Sperber LM, Kane SA, Tong Z, Tong AH, Boone C, Bi E (2007). Sequential and distinct roles of the cadherin domaincontaining protein $\mathrm{Ax|} 2 \mathrm{p}$ in cell polarization in yeast cell cycle. Mol Biol Cell 18(7): 2542-2560. doi: 10.1091/mbc.e06-09-0822

157. Kang PJ, Hood-DeGrenier JK, Park H-O (2013). Coupling of septins to the axial landmark by Bud4 in budding yeast. J Cell Sci 126:12181226. doi: 10.1242/jcs.118521

158. Cvrckova F, Nasmyth K (1993). Yeast G1 cyclins CLN1 and CLN2 and a GAP-like protein have a role in bud formation. EMBO J 12(13):5277-5286. doi: 10.1002/j.1460-2075.1993.tb06223.x

159. Benton B, Tinkelenberg AH, Jean D, Plump SD, Cross FR (1993). Genetic analysis of $\mathrm{Cln} / \mathrm{Cdc} 28$ regulation of cell morphogenesis in budding yeast. EMBO J 12(13):5267-5275. doi: 10.1002/j.14602075.1993.tb06222.x
160. Park H-O, Sanson A, Herskowitz I (1999). Localization of Bud2p, a GTPase-activating protein necessary for programming cell polarity in yeast to the presumptive bud site. Genes Dev 13(15):1912-1917. doi: 10.1101/gad.13.15.1912

161. Marston AL, Chen T, Yang MC, Belhumeur P, Chant J (2001). A localized GTPase exchange factor, Bud5, determines the orientation of division axes in yeast. Curr Biol 11(10):803-807. doi: 10.1016/s09609822(01)00230-5

162. Kang PJ, Lee B, Park H-O (2004). Specific residues of the GDP/GTP exchange factor Bud5p are involved in establishment of the cell typespecific budding pattern in yeast. J Biol Chem 279(27):27980-27985. doi: 10.1074/jbc.C400175200

163. Krappmann AB, Taheri N, Heinrich M, Mosch HU (2007). Distinct domains of yeast cortical tag proteins Bud8p and Bud9p confer polar localization and functionality. Mol Biol Cell 18(9): 3323-3339. doi: 10.1091/mbc.e06-10-0899 